TI E PROSPECTS FOR OFFICIALLY SANCTIONED PRIVATE SECTOR PARTICIPATION IN PAK-AFGHAN FERTILIZER AND MACHINERY TRADE AND 'TRANSPOIRT 


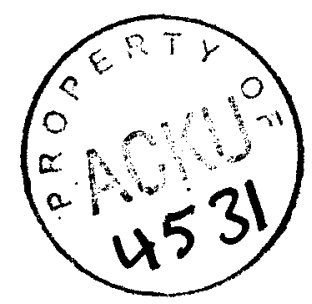

THE PROSPECTS FOR OFFICIALLY SANCTIONED

PRIVATE SECTOR PARTICIPATION IN PAK-AFGHAN

FERTILIZER AND MACHINERY TRADE AND TRANSPORT

prepared under

Contract No. 304-0204-C-00-9829-00, O/AID/REP, Islamabad Afghanistan Agricultural Sector Support Project (ASSP)

EDC subcontract with Development Alternatives, Inc.

Work Order No 2

May 1991

EDC (Pvt.) Limited

Enterprise \& Development Consulting

40-A Kaghan Road, F-8/4 (P.O. Box 2389) Islamabad, Pakistan

Tel: (92-51) 852863; Fax: (92-51) 822313; Tlx: 5811 NAIBA PK 
Page No.

List of Abbreviations iv

Background to the Assignment v v

REPORT NO. 1:

ON FERTILIZER IMPORTS

1.1 The "Standard" Policy 1

1.2 Steps Involved in the standard Procedure 1

1.3 General Issues and Problem Areas for ASSP 2

1.4 Formalities Required for clearance of Shipment

1.5 Octroi and Other Taxes Payable During
Transportation from Karachi to the Borders

1.6 Requirements for Bonded Warehouses $\quad 5$ General Policy and SROs 5 Procedural Steps $\quad 6$

Issues and Problem Areas 6

1.7 Existing Transit Facilities
Provided by GOP to the Afghan Government

Articles of the Pak-Afghan Treaty 7

Other GOP Transit Trade Regulations $\quad 10$

$\begin{array}{lll}1.8 & \text { Recommendations } & 10\end{array}$

REPORT NO. 2 :

ON AGRICULTURAL MACHINERY AND EQUIPMENT 12

2.1 Overall Regulatory Environment 13

Tractors 13

Agricultural Implements

$\begin{array}{ll}\text { Sprayers } & 14\end{array}$

2.2 General Issues and Problem Areas for ASSP 14

2.3 Financial Mechanisms Available for Purchasing
the Equipment 
2.4 Description of $\mathrm{L} / \mathrm{Cs}$ and

the Steps Involved in Opening an $\mathrm{L} / \mathrm{C}$

Collateral Requirements

2.5 Dealership Networks Extending into Afghanistan 16

2.6 Incentives Required to Stimulate Manufacturers $\quad 16$

$\begin{array}{lll}2.7 & \text { Warehousing Arrangements } & 17\end{array}$

2.8 Insurance Types and Mechanisms Aimed at

Lowering the Risk of Pakistani Manufacturers 17

2.9 Recommendations $\quad 17$

ANNEXURES 19

1. Responses to Questions Raised by
Mr Rick Gilmore, ASSP Consultant

2. General Terms of References for the Study 25

3. Correspondence between EDC and CBR 28

SEPARATELY BOUND ATTACHMENT:

Relevant Extracts from The Export Policy Order, 1990, and the Customs Act, 1969, the latter including the chapters on Declaration of Ports, Airports, Land Customs stations, Etc.: Warehousing; Trans-shipment; and Transit Trade. 


\section{List of Abbreviations}

ASSP

CBR

CCI\&E

CIF

DAP

FID

FOB

GOP

IRC

KMC

$\mathrm{L} / \mathrm{C}$

MTL

NLC

SRO

TRP

TORS

UNHCR

UNICEF

Afghanistan Agricultural Sector Support Project Central Board of Revenue

Chief Controller Imports and Exports

Cost, Insurance and Freight

Di-Ammonium Phosphate Fertilizer

Fertilizer Imports Department

Free on Board

Government of Pakistan

International Red Cross

Karachi Municipal Corporation

Letter of credit

Millat Tractors Limited

National Logistics Cell

Statutory Revenue order

Temporary Registration - Peshawer

Terms of Reference

United Nations High Commission for Refugees

United Nations Children's Fund 
Development Alternatives Inc. requested EDC on September 11, 1990 to provide the Afghan ASSP with an update on the Government of Pakistan's (GOP) regulatory framework regarding imports and transit trade. EDC's Tariq Rahim Anwar visited the project office in Peshawer on September 26 and discussed the scope of work with Mr David Garner and Mr Denny Freed.

As requested by Mr Garner, EDC submitted the draft ToRs for the study on October 2, 1991 to DAI. (Annex 2). On October 4, Mr Garner informed the consultant that the ToRs were generally suitable and appropriate, and that there might be some adjustments/amendments down the line.

Initial work on this assignment started on october 9 when Tariq Rahim Anwar visited Karachi to join Messrs. Dennis Freed and John Soden who were there to meet with representatives of the Afghan consortium planning to import 10,000 metric tons of fertilizer. The consultant also met with the managing partners of International Forwarding Agency to discuss the clearing and transportation of fertilizer from Karachi to the border towns of Chaman and Peshawer.

On returning to Islamabad, the consultant met with the Member (Customs) of the Central Board of Revenue (CBR), who asked the consultant to see him after the October 1990 general elections. On October 31 the consultant met Member (Customs) and submitted an application to obtain the required information (Annex 3). The application was marked to Ms Adeela Rehman, Second secretary Customs, dealing with bonded warehouses. During the first week of November, the consultant met with different second secretaries at the CBR, each dealing with law and procedures, bonded warehouses, budget, tariffs, customs exemptions and transit trade. However, they all declined to give the information verbally unless the file was marked to them.

In the third week of November, Mr Richard Gilmore of GIC, an Assp consultant, sent a number of questions to augment the ToRs. The consultant's responses to his questions are included in this report at Annex 1. Mr Gilmore particularly emphasized the importance of his questions on fertilizer issues.

During the period December 1990 to March 1991, CBR did not respond to the consultant's request for information despite several visits to that office. On the other hand, officials at the Ministry of Commerce asked the consultant to obtain the required information from CBR.

In March 1991 a new second secretary was posted in the warehousing section of $\mathrm{CBR}$ who asked for some time before he could 
respond to our request. However, in April 1991 he informed the consultant to look for the required information in the customs Regulations given in the statutory Revenue Orders (SROs) which are issued by the Federal Government from time to time, and the customs Act of 1969. Similarly, the Chief Controller Imports and Exports (CCI\&E) asked the consultant to refer to the GOP's standard import/export policies.

The experience of this assignment is that Government officials will not provide policy-related answers to the kind of questions in which AssP is most interested. Experience and discussions strongly suggest that responses from the Government should be elicited on specific requests for action or ispecial case exemptions' required for the implementation of various AssP initiatives.

The information and recommendations provided in this report are based on informal opinions of GOP officials, discussions with knowledgeable private sector parties, and publications on GOP laws and regulations. Following the TORs, "two short but comprehensive reports" are contained in this volume, one each on fertilizer and agricultural machinery. The contents of the two reports follow the specific TORs for each subject, although additional information is also provided. A separately bound attachment to this report reproduces relevant extracts from The Export Policy order, 1990, and the Customs Act, 1969, the latter including the chapters on Declaration of Ports, Airports, Land Customs stations, Etc.; Warehousing; Trans-shipment: and Transit Trade. 
Report No. 1

On

Fertilizer

Imports 


\subsection{The "Standard" Policy}

The GOP imports fertilizer (including DAP) through the Pakistani indentors of international fertilizer companies. According to our discussions with importers and indentors of fertilizers and officials of FID, the current GOP policy to route fertilizer imports through the FID has the following rationale:

1. There are no import duties or other surcharges on fertilizer imports; and,

2. Fertilizer sale prices are subsidized by GOP.

Given the importance of fertilizer to Pakistan's agriculture, GOP wants to have exclusive control over its imports rather than letting the private sector determine its supply, demand or prices. In addition, it should be noted that fertilizer is not available, under the current regulations, for re-export to any country.

The GOP invites sealed tenders from the indentors for the import of a specific quantity of fertilizer. The prices have to be quoted on fob basis (in metric tons); in addition, the tenders have to specify the country of origin and the shipping charges. This is important because all fertilizer imports are made under various barter agreements with different countries. Most of the DAP is imported either from Jordan or the U.S.A. The tenders are opened at a specified date at the Ministry of Agriculture (FID), and then the best and final prices are negotiated with prospective importers. The FID awards the tender to the most competitive firm (in some cases contracts for part shipments are awarded to more than one indenting firm).

Once the fertilizer arrives at Karachi port, the GOP arranges for its clearance/transportation to various destinations in the four provinces. The various steps for clearance and transportation are described in the following sections:

\subsection{Steps Involved in the standard Procedure}

According to CBR officials, the following steps will be required for import of DAP:

1. Invitation for bids by the FID of the Ministry of Food, Agriculture and Co-operatives for a specified quantity (quotations on fob and CIF basis). This is explained above in section 1.1 .

2. Submission, evaluation and award of contract for 
importing the fertilizer to the lowest bidding private sector firm. Sometimes, different firms are awarded the contract for part-shipment.

3. Opening of an $\mathrm{L} / \mathrm{C}$ by the winning firm(s) within a period specified in the Public Notice issued by the CCI\&E. ${ }^{1}$ An irrevocable $\mathrm{L} / \mathrm{C}$ has to be opened with a scheduled bank in Pakistan. The bank is, it may be noted, empowered to extend or revalidate the established $L / C$ within its validity period.

4. Import/shipment of fertilizer from the country of origin. As noted earlier, most of the DAP currently originates from Jordan or the U.S.A.

5. Filing of bill of entry for warehousing. This shall be required if the shipment has to be placed in a warehouse as explained in section 1.6 .

6. Clearance at port and transportation to the various fertilizer depots. The fertilizer is stored in depots all over the country owned by the National Fertilizer Corporation (NFC) and other private sector producers of urea fertilizer including Exxon and Dawood Hercules.

7. An export-cum-import permit for re-export to Afghanistan which is issued by the Chief Controller Imports and Exports ${ }^{2}$.

\subsection{General Issues and Problem Areas for ASSP}

As indicated by the above steps, the general issues and problem areas for the Afghanistan ASSP exist because of the absence of any provision in the GOP regulations for DAP imports/re-export by the private sector. In summary, the following major problems have been identified after discussions with GOP and indentors, and a review of various CCI\&E and CBR regulations:

i) An exemption from the CBR would be needed to seek permission to import and re-export DAP fertilizer. According to CBR officials, unless there is an intervention at a high level on

1 This is in case of imports under barter only; for licenses against cash, loans or credits, the L/C has to be opened within a period of one hundred and eighty days.

2 According to CBR officials, this permit will be required if the fertilizer is to be re-exported to Afghanistan. 
behalf of ASSP, exemption will not be granted under normal circumstances because:

1. The GOP does not want to formalize any trade with Afghanistan (a foreign policy issue): and,

2. The ASSP plans to store the fertilizer in depots at the borders for an unspecified period of time. As a result, and in case of an increase in the international prices of fertilizer, the GOP fears that the DAP may actually be dumped in the Pakistani market instead of going to Afghanistan.

ii) A question was raised whether or not ASSP intends to have a subsidy on the fertilizer. If it does not, an exemption would be required from the CBR. However, if a subsidy is sought from the GOP, then the shipment may not be available for reexport under the current regulations.

iii) The timely availability of Railway wagons for transportation of DAP from Karachi port to the border depots is very doubtful.

\subsection{Formalities Required for \\ clearance of shipment at the Rarachi Port}

Once the shipment has arrived at the Karachi Port, a Bill of Entry will be made. This will indicate all the relevant information regarding the imported goods including a certificate of origin, price list and packing size.

A Pro-forma Invoice will be made indicating the C\&F value and the quantity of imported goods.

A Quarantine Certificate will be required before the goods are removed from the port area.

with all the documentation taken care of, the goods may be either removed from the vessel and stored temporarily, or loaded directly on the transport for up-country movement.

\subsection{Octroi and Other Taxes Payable During Transportation from Karachi to the Borders}

Generally, all goods (including fertilizer) are exempt from payment of all octroi and other taxes payable during transportation. However, ASSP will need to pay the following taxes 
in case the fertilizer is transported by road to the border destinations:

1. Karachi Dock Labor Board Cess, payable before the shipment is removed from the port, at the rate of Rs 5.20 per metric ton. No exemption is allowed on this cess.

2. Octroi needs to be paid to Karachi Municipal Corporation. In case the goods in question are meant for a place other than the KMC limits, KMC may issue an Exemption Certificate, only if it is satisfied that the final destination of the goods is outside the KMC limits.

\subsection{Requirements for Bonded Warehouses}

\section{General Policy and SROs}

Bonded warehouses are governed by sections 84 to 119 of the Customs Act, 1969 and related Customs SROs (cited below). In general the use of bonded warehouses is applicable only when dutiable goods have entered the country and assessed under section 80 of the Customs Act.

The facility of bonded warehouses, according to the customs Act, is provided for the following users:

1. Importers of raw material etc. (who can have a bonded warehouse at their factory premises) who do not wish to pay the entire import duties on the shipment at Karachi;

2. Operators of commercial bonded warehouses who store the goods for the consumption/purchase of the diplomatic community including the privileged foreign nationals who have been exempted from payment of customs duties by the CBR; and,

3. Goods intended for transit, and placed in designated 'customs areas'.

Following are the relevant SROs issued by GOP to govern the use of bonded warehouses:

o SRO 263 (I)/70, dated 29th October, 1970. This SRO prescribes the procedure for filing an application for leave to deposit goods in a warehouse.

- SRO 131(I)/71, dated 20th April, 1971. A pro forma for the warehousing bond is prescribed under this SRO. 
SRO 1247 (I)/82, dated 16th November, 1982. The prevailing rates of warehouse storage fees per week are specified under this SRO.

\section{Procedural steps}

Generally, the following steps are involved in the opening and operation of bonded warehouses:

1. The permission to open a warehouse is granted by the collector of customs in case the application is in line with current SROs and no exemptions are-required from the CBR;

2. A secured and covered godown/store is provided by the applicant, which has to meet the standard CBR requirements:

3. The salary and other living costs of a godown keeper appointed by the customs department are to be borne by the operator of the warehouse, and an undertaking to meet such expenses is needed:

4. The goods imported are kept in the warehouse under the customs seal, and only the customs godown keeper is authorized to open the warehouse; and,

5. The required quantity may only be taken out from the warehouse after payment of all customs duties and taxes.

\section{Issues and Problem Areas}

It appears that the issue of bonded warehouses requires decisions and actions according to the following options:

1. In case ASSP requests a subsidy on imported fertilizer, GOP will insist on bonding the shipment at the border depots. According to various sRO notifications, such warehouses can be opened in Chaman and Peshawer Districts.

2. In case no subsidy is requested by ASSP, the shipment will have to be placed in a designated 'customs area' which is in Peshawar District. As such, the question of

3 All goods in transit and meant for re-export have to be kept in the designated customs areas of the GOP, as stipulated in various SROs. 
having depots at the border areas (tribal areas) will have to be put to the CBR in the form of an application for a specific exemption.

\subsection{Existing Transit Facilities \\ Provided by GOP to the Afghan Government}

\section{Articles of the Pak-Afghan Treaty}

Since the end of 1979 GOP has suspended all transit trade facilities to the Afghan Government. For purposes of reference, however, and in view of the questions raised in the original and supplementary ToRs, the main articles of the treaty between the Pakistan and Afghan Governments are given below.

\section{Article I:}

The Contracting Parties undertake in accordance with the provisions of this Agreement to grant and guarantee to each other the freedom of transit to and from their territories.

No distinction shall be made which is based on the flag of the vessels, the place of origin, departure, entry, exit or destination or any other circumstances relating to the ownership of goods, of vessels or of other means of transport.

\section{Article II:}

Goods including baggage, and vessels and other means of transport shall be deemed to be in transit across the territory of Contracting Party, when the passage across such territory with or without transhipment, warehousing, breaking bulk or change in the mode of transport, is only a portion of a complete journey beginning and terminating beyond the frontier of the contracting Party across whose territory the traffic passes. Traffic of this nature is termed in this Agreement "Traffic in Transit".

\section{Article III:}

The transit routes shall be:

1. Peshawar - Torkham and vice versa.

2. Chaman - Spin Boldak and vice versa.

4 Annexures to the treaty are reproduced in a separately bound attachment to this report, under Chapter XIII 'Transit Trade' from the Customs Act, 1969. 
Additional routes may be agreed between the contracting Parties from time to time. Goods moving via these routes shall be entered at the proper customs Post prescribed by each Party. Adequate transit and other facilities shall be provided by the contracting Party concerned at these posts.

\section{Article IV:}

No custom duties, taxes, dues, or charges of any kind whether national, provincial or municipal regardless of their names and purposes, shall be levied on traffic in transit except charge for transportation of those commensurate with the administrative expenses entailed by traffic in transit or with the cost of services rendered.

With a view to achieving simplification of existing Customs practices and procedures, the contracting Parties agree to adopt at points of entry and exit the procedures laid down in the Annex to this Agreement.

\section{Article v:}

Without prejudice to the generality of the provisions contained in Article III, the Government of the Islamic Republic of Pakistan shall earmark sheds and open spaces in Karachi Port Area, to be known as Afghan Transit Area, for the goods in transit to and from Afghanistan. For hazardous and awkward goods separate arrangements for storage will be made as indicated in the Annex.

\section{Article VI:}

The Two Contracting Parties, recognizing the importance of the Kabul-Torkham-Peshawar transit route, have decided to examine all matters pertinent to the development of this route, including further consideration of the extension of the railway from LandiKhana to Torkham.

\section{Article VII:}

The Government of the Islamic Republic of Pakistan undertake to meet in full the requirement of wagons for transit traffic on both Karachi-Spin Boldak and Peshawar-Karachi routes.

\section{Article VIII:}

Each Contracting Party shall appoint Liaison officers to look into the working of this Agreement, and to refer, for expeditious solution, to the appropriate authorities of their own country and to Liaison officer of the other country, any question arising from the operation of this Agreement. The Liaison officers will meet as often as necessary and in any case not less than once in six 
months and the contracting Parties shall provide them with the necessary facilities.

\section{Article IX:}

The Contracting Parties agree that railway freight, port and other dues shall be subject to the most sympathetic consideration and shall be no less favorable than those imposed by either Party on goods owned by its own nationals.

\section{Article $x:$}

Nothing in this Agreement shall be construed to prevent the adoption and enforcement by either Party of measures necessary to protect public morals, human, animal or plant life or health and for the security of its own territory.

\section{Article XI:}

The Contracting Parties shall meet and consult each other once a year to review the working of this Agreement.

\section{Article XII:}

The Contracting Parties agree to resolve any difference relating to the interpretation of this Agreement by negotiation, and in the event of failure to reach a settlement, to refer the matter to an arbitrator acceptable to both Parties, whose decision shall be binding.

\section{Article XIII:}

Nothing in this Agreement or its Annexes will affect in any way the political stand of the two countries or the political difference existing between them, and the contracting Parties fully reserve their rights with regard to these subjects.

\section{Article XIV:}

This Agreement shall be ratified and the instruments of Ratification shall be exchanged at Rawalpindi. The Agreement shall come into force from the date of the exchange of the Instruments of Ratification and shall remain in force for five years from the date it comes into force. Unless notice or termination is given in writing by either Contracting Party to the other six months before expiration of the five years' period the Agreement shall be automatically renewed for a further period of five years. It can therefore be terminated by either Party at any time provided six months notice of termination is given by either Party. 


\section{other GOP Transit Trade Regulations}

Other transit trade regulations of the GoP are covered under sections 126 to 138 of the Customs Act, 1969. In addition, relevant SROs relating to transit trade are as follows:

i) SRO 1332 (I)/73, dated 17th September, 1973 .

This SRO specifies the rules for transhipment of goods

by the Pakistan Railways or another means of conveyance approved by the CBR. Besides other procedural matters, the SRO addresses the issues of sealing and security of transport units and documentation required.

ii) SRO 185(I)/74, dated 14th February, 1974.

This SRO is titled Customs Export Transit Rules, 1974, and deals with all related procedural issues.

iii) SRO 125(I)/83, dated 12th February, 1983.

This SRO specifies the restricted goods which cannot be transshipped across the Pakistan borders (the list of restricted items does not include fertilizer or agriculture machinery).

\subsection{Recommendations}

Based on a review of available literature and discussions with GOP officials, fertilizer importers and transporters, it is recommended that DAI/ASSP:

i) Review the CBR's exemption granted to UNICEF, UNHCR and IRC for goods supplied to Afghan refugees under SRO No. SRO 951 (I)/87, dated 8th December, 1987. The consultants were informally informed by CBR that ASSP can obtain an exemption for the proposed import of DAP on similar lines, provided that the matter is taken up at a very high level in the GOP;

ii) Apply for an exemption to the CBR to include containerized trucks (being operated by the NLC and private transporters) in the definition of 'carrier' of the Customs Act, which presently includes Pakistan Railways only. This is important because the availability of railway wagons in Karachi is a very acute problem, and a delay in transportation may result in incurring exorbitant demurrage charges at the Karachi port; and,

iii) Import the fertilizer in bulk (instead of importing bagged fertilizer) in order to benefit from the cost difference. Under the current rules, bags for fertilizer may be imported free of any 
duties with the fertilizer shipment. The fertilizer shipment can be put in bags at Karachi conveniently since the port has the necessary suction machinery required for 'bagging' the bulk fertilizer. 
Report No. 2

On

Agricultural

Machinery

and

Equipment 


\subsection{Overall Regulatory Environment}

In the context of ASSP, the proposed program involving agricultural machinery and implements can be categorized as follows :

1. Tractors - imported or locally manufactured;

2. Agricultural implements - locally manufactured; and,

3. Sprayers and similar imported machinery.

A brief discussion of the regulatory environment for each of these categories is given below.

\section{Tractors}

According to the Marketing Manager of Millat Tractors Ltd (a Public Sector organization manufacturing Massey Ferguson tractors), the proposed DAI plan seems to be workable, provided that the project can formalize exports to Afghanistan. The main issue, according to him, shall be the currency of payment. As long as the payment is not made in foreign currency by the Afghans, the GOP shall not formalize the exports. In other words, with rupee payments only the existing informal channels may be used by the ASSP.

The tractor manufacturers meeting AID's source eligibility requirements are in the public sector - Millat and Al-Ghazi. The other private sector organizations, namely, Associated Engineering and Fecto Belarus, assemble Yugoslav and Russian tractors respectively. The makers of Ford tractors, Allied Engineering, have discontinued service.

In case the project decides on importing the tractors, exemptions from GOP will be needed for import and re-export by the project. As in the case of fertilizer, there are no duties on import of tractors (of categories not manufactured/assembled in Pakistan) in 'completely knocked down' condition.

\section{Agricultural Implements}

The manufacturer of agricultural implements is largely in the private sector. It is interesting to note that a number of private

1

Al-Ghazi has been offered to the private sector for sale recently. 
sector manufacturers are generally involved in informal trade with Afghanistan. Initial discussions with them revealed that they are generally interested in the project provided due incentives (such as those listed in section 2.5.) are offered to them.

The relevant SRO granting exemption from all customs duties on agricultural equipment is SRO 505 (I)/88, dated 26 th June, 1988 .

\section{Sprayers}

The sprayers will have to be imported, and exemptions from CBR will be required.

\subsection{General Issues and Problem Areas for ASsP}

The general issues are quite similar to the problems identified in Report No. 1. In other words, several specific exemptions from the CBR would be required to:

1. Seek import cum-export permits for specific items;

2. Obtain permission to bond the machinery in warehouses at the borders:

3. Seek permission from the Ministry of Finance and the state Bank of Pakistan to accept local currency in exchange for the machinery/equipment exported to Afghanistan:

4. The manufacturers (especially in the private sector) are only interested in the program if advance cash payments are made to them; and,

5. Leasing or rentals do not seem to be practical under the current circumstances.

\subsection{Financial Mechanisms Available for Purchasing the Equipment}

According to some manufacturers, either of the following three mechanisms are acceptable to them:

1. Leasing:

2. Rental; and,

3. Cash sale. 
For the first two options, however, the manufacturers would require absolute bank guarantees from a scheduled bank on behalf of the project, since the machinery/implements would be shipped across the border.

Generally, leasing and rentals arrangements seem not to be practical because of the prevailing uncertain circumstances in Afghanistan. Even otherwise, it does not seem practical unless bank guarantees are provided to the manufacturers since the equipment will be across the border and re-possession by the owners in case of default will be impossible. ${ }^{2}$

\subsection{Description of $\mathrm{L} / \mathrm{Cs}$ and the steps Involved in opening an $\mathrm{L} / \mathrm{C}$}

\section{Steps for Opening $\mathrm{L} / \mathrm{Cs}$}

A general introduction to leasing and different types of $\mathrm{L} / \mathrm{Cs}$ is given in Tariq Husain's consultancy report prepared for ASSP under the DAI/EDC subcontract Work order Number 1. The steps and documentation required for opening Import $\mathrm{L} / \mathrm{C}$ and Inland $\mathrm{L} / \mathrm{C}$ are given below.

\section{Opening an Import L/C:}

1. Opening of account with the Bank, and an L/C application;

2. Obtaining the Category Passbook from the Chief Controller Import and Exports (CCI\&E):

3. Obtaining Import License from CCI\&E;

4. Submission of a duly attested pro forma invoice: and,

5. Having a valid insurance policy for the goods.

Opening an Inland L/C:

1. Submission of $\mathrm{L} / \mathrm{C}$ application to the bank: and,

2. Submission of a duly attested proforma invoice, or order of consignment or indent.

2 One way around this would be for ASSP to guarantee repayment. 


\section{Collateral Requirements}

The collateral requirements are generally based on the approved facility from the bank, and vary from bank to bank. In addition, customer track record and the risks associated are also considered before collateral is specified. However, in general terms, the following collateral is required by the banks:

1. Mortgage on immovable property in favor of the bank;

2. Hypothecation of property and goods; and,

3. The collateral is fully secured by cash or equivalent (government securities etc.).

\subsection{Dealership Networks Extending into Afqhanistan}

The private sector manufacturers are generally not interested in having a dealership network spread across the border. However, MTL is willing to appoint agent(s)/dealer(s) in Afghanistan, provided that ASSP offers certain guarantees mentioned in Section 3.2. In addition, MTL has also expressed willingness to train the Afghani technical and sales personnel in Pakistan at a suitable location near the borders.

\subsection{Incentives Required to Stimulate Manufacturers}

Discussions with MTL and private sector manufacturers in Faisalabad and Lahore revealed that the Pakistani manufacturers will be interested in the ASSP program if at least the following three incentives are offered to them:

1. Formal purchase orders issued (at least in the initial stages) by the ASSP;

2. Advance payment in cash along with the purchase order; and,

3. The program involves a high volume of tractors and implements trading across the border. It may be noted that the domestic market has a very high demand for agricultural machinery including tractors, and Pakistani manufacturers will be interested only if the ASSP program offers them promising prospects for Afghanistan. 


\subsection{Warehousing Arrangements}

There are no specific Customs laws or SROs guiding warehouse requirements in case of formal exports. The private sector manufacturers did not show any particular interest in warehouse facilities near the borders. MTL, however, proposed the following arrangements:

1. Stock the tractor/implements in the border area or anywhere near the border through a MTL agent/dealer, provided full payment is paid to the company at least in the initial stages of the program;

2. Facility of provision of a full range of tractors and implements at a short notice from MTL, Lahore;

3. After-sales service in Afghanistan through the Afghani agent or near the border through a local MTL agent/dealer, including a guarantee to provide spare parts; and

4. All arrangements from booking to delivery at the warehouse in Pakistan will be taken care of by MTL.

It should be noted that the current production capacity of MTL is 60 tractors per day, and therefore, the time lag between the booking and delivery time is a maximum of 30 days.

\subsection{Insurance Types and Mechanisms}

Aimed at Lowering the Risk of Pakistani Manufacturers

There are insurance policies providing full coverage against fire, accident, theft, etc. available for transportation from Karachi to the borders. Similarly, while the goods/equipment are kept in bonded warehouses at the border, insurance coverage is mandatory. However, currently there is no formal insurance available for goods transported across the border to Afghanistan.

\subsection{Recommendations}

Based on the above observations and discussion, it is recommended that ASSP:

i) Obtain specific exemptions from the CBR before proceeding with the program, in particular regarding: 
1. Permission to import machinery and equipment for reexport:

2. Transit facilities at the borders. The Afghan buyers cannot visit the customs warehouses in order to see/inspect the equipment. Therefore, an alternative arrangement shall have to be made with the CBR/GOP in case the sales depots are provided in Pakistan.

3. Resolve the issue of the currency of payments with the state Bank of Pakistan.

ii) Provide the private sector manufacturers the desired incentives, because the program cannot depend solely on MTL. 
Annexures 
1. Identify the GOP export duty regulations, to include a list of those products that are assessed duties and their rate schedules; also a list of those products banned from export.

\section{Answer:}

The export duty regulations are governed by the trade policy of the GOP which is revised on an annual basis. These rates are prescribed in the First schedule and the second schedule under section 18 of the Customs Act, 1969, and amended annually by the Federal Government. The Customs Tariffs provides the following information:

- Customs imports tariff with sales tax on imports and local manufacture;

o Customs exports tariff; and,

- Export rebates.

2. Identify the GOP import requirements, i.e., customs duties, taxes etc. List import options and their respective regulations, requirements covering such items such as transit trade and counter-trade.

\section{Answer:}

The general import requirements are given as following:

a. Obtaining of the Import License from the CCI\&E; and,

b. Opening of an irrevocable $\mathrm{L} / \mathrm{C}$.

3. Is there a law on the books which exempts imports from any origin into Pakistan from any import or export duty provided the item is a re-export from Pakistan and that there has been a minimum of $10 \%$ value added to the item within Pakistan? 


\section{Answer:}

i) Exemptions can be given by the CBR on a case by case basis.

ii) Some traders have reported that they have extensively used the "10\% value added" rule for importing goods into Pakistan, and then re-exporting them to Afghanistan.

iii) Since the promulgation of the Customs Act, 1969, several SROs have been issued by the CBR granting exemption of customs duties and sales tax on goods imported with a view to subsequent exportation, or on export of certain goods. SROs relating to agricultural products and chemicals are listed below:

o SRo 576 (I) $/ 74$, dated 10th May, 1974.

- SRO 674 (I) $/ 80$, dated 26th June, 1980 .

- SRO 881 (I) $/ 80$, dated 23rd August, 1980.

o SRO 461 (I) $/ 88$, dated 26th June, 1988.

o SRO 818 (I)/89, dated 9th August, 1989.

o SRO 576 (I)/74, dated 10th May, 1974.

o SRO 640 (I)/83, dated 18th June, 1983.

- SRO 481 (I)/88, dated 26th June, 1988 .

4. Also include an examination of government to government agreements that exist or changes contemplated between the GOP and both the USA and Afghanistan. How do these affect the private sector relative to transportation and trade?

\section{Answer:}

To the extent that we are aware of the Pak-Afghan trade and transit treaty, we already know the answer to this question. Attempts to elicit general policy statements from GoP are not likely to be successful (as indicated by experience to date).

Relevant SROs are cited below:

- SRO 491 (I)/88, dated 26th June, 1988.

- SRO 492 (I) $/ 88$, dated 26 th June, 1988. 
The' relevant articles of the agreement ${ }^{3}$ between the GOP and the Afghan Government for regulation of traffic in transit are given in Section 1.7 of the main report.

5. Is there a special regulation concerning the jurisdiction of foreign national (Afghan) versus Pakistani truckers? Are Afghan loaders legally allowed to load or off-load at chaman or goods must be delivered/received by Afghan truckers within Afghanistan?

\section{Answer:}

Under the trade and transit treaty between Pakistan and Afghanistan, both Pakistani and Afghan truckers are allowed to load/off-load at Afghan and pakistani border towns respectively. Presently, Afghan vehicles with Temporary Registration Numbers (TRP) given by the GOP can operate freely both in Pakistan and Afghanistan.

6. Provide information on the establishment and use of bonded warehouses.

\section{Answer:}

The bonded warehouses are governed by sections 84 to 119 of the Customs Act, 1969 and the related Customs SROs. In general the use of bonded warehouses is applicable only when dutiable goods have entered the country and assessed under section 80 of the Customs Act. Such warehouses can be opened in Chaman and Peshawer districts.

Other SROs issued by the GOP to govern the use of bonded warehouses are given as following:

o SRO 263 (I) $/ 70$, dated 29th October, 1970.

o SRO 131(I)/71, dated 20th April, 1971.

o SRO 1247 (I)/82, dated 16th November, 1982 .

other details are provided in section 1.6 of the main report.

3 This agreement is suspended currently 


\section{Assess the impact of the recent hike in oil prices on prices}

of DAP fertilizer.

\section{Answer:}

There has not been any major impact of the oil price increase on prices of DAP fertilizer. The August-September, 1990 (fob) prices of DAP in the international market were $\$ 185.00$ per metric ton. However, the price jumped to approximately \$200-205 per metric ton in January 1991. Rather than the hike in oil prices, the two most notable factors for the increase in DAP are:

i) DAP production of Jordan (one of the biggest producers of DAP) was not available for exports (through the port of Aqaba) because of the situation in the Gulf. As such, this curtailment in supply led to a higher market price; and,

ii) About one million tons of fertilizer were reportedly bought by Iran, china and India during this period. Therefore, a higher demand coupled with the above factor resulted in an increase in DAP prices.

However, the C\&F prices of DAP in Pakistan increased by approximately $\$ 2$ per metric ton because of the oil prices hike and limited cargo availability in this region.

The following are the recent price trends of DAP:

\begin{tabular}{ll}
\multicolumn{1}{c}{ Period } & Price, $\$ /$ met \\
\cline { 2 - 2 } December 1989 & $190-191$ \\
September 1990 & 185 \\
February-March 1991 & $204-205$
\end{tabular}

8. Would the Pakistani Banking Council allow its member banks to accept letters of credit (L/C) issued by Afghani banks?

\section{Answer:}

The Pakistan Banking Council does not allow its member banks to accept L/Cs issued by Afghani Banks, since all trade between the two countries is officially closed.

9. If the answer to the above is negative, then what major international banks are correspondent banks of (i.e.have relations with) Kabul banks?

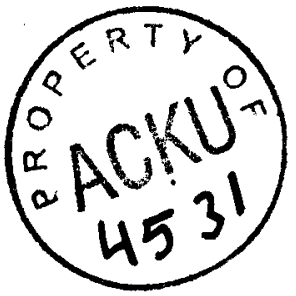




\section{Answer:}

None of the international banks operating in Pakistan are correspondent banks of the Afghani banks. Therefore, the Pakistani banking channels cannot be used for trade with Afghanistan under the current circumstances. ${ }^{4}$

\footnotetext{
${ }^{4}$ Source: Discussions with Bank of America officials.
} 


\section{General Terms of Reference for the study}

The Afghan ASSP is arranging for off-shore fertilizer imports through a consortium of Afghan Traders; it also plans to facilitate trade of agricultural equipment and machinery. The general purpose of this short term assignment is to provide ASSP with a detailed account of the regulatory environment of the GOP and the provincial governments pertaining to (a) fertilizer imports, transit facilities, custom regulations, and warehousing at the Afghan border; and (b) the potentials for Pakistani agricultural equipment and machinery utilization by Afghans across the border.

The consultant will work with Mr John Soden and Mr Denny Freed for a period of one month or more to compile information under the following categories:

i) Detailed information that would be needed by ASSP in terms of identification of the fertilizer import process, import regulations, octroi taxes, and bonded warehouse requirements, and identification of major road blocks at each stage.

ii) Detailed information on agricultural equipment and machinery that is needed in terms of letters of credit, manufacturer incentives, dealership networks, insurance types, etc.

iii) Provide recommendations to streamline the systems described in i) and $i i)$.

iv) Assist ASSP senior staff in identifying government offices and officers with whom high level contacts need to be made to overcome existing and anticipated road blocks.

The consultant will not be expected to negotiate with or recommend specific banks or equipment manufacturers, but he will provide sufficiently detailed information for selection and negotiation by ASSP.

\section{Timing and Duration}

The consultant is expected to spend at least one month on this assignment, starting o/a October 07, 1990. If, at the end of that month, ASSP requires additional information on the subject of this assignment (or related subjects), it may renew the assignment for another month or part thereof. 


\section{Review of Documents}

The consultant is expected to review the following documents at the time of commencing his assignment:

i) Consultancy report by Tariq Husain.

ii) Strategy and Plan of Work of ASSP.

iii) Consultancy report by Roger Poulin.

iv) TDY report by Denny Freed.

v) Any other reports and papers recommended by the Chief of Party of ASSP or his designee.

\section{Meetings and Visits}

The consultant will meet with:

i) All project staff indicated by the cop or designee, including but not limited to Mr David Garner, Mr John Soden and Mr Denny Freed.

ii) Concerned GOP officials in FDFI and CBR in Islamabad and Karachi.

iii) Bankers dealing in stand-by LCs in Lahore, Rawalpindi and Peshawar.

iv) Management of selected few equipment manufacturers.

\section{Reports}

It is expected that the consultant will, at a minimum, prepare two short but comprehensive reports, providing information on fertilizers and agricultural equipment and machinery. The contents of the reports will include the following items:

\section{On Fertilizer Imports}

i) List all the steps involved in the import of fertilizers to Pakistan. 
ii) Required formalities for clearance of shipment at the Karachi Port.

iii) Information on the octroi and other taxes needed to be paid during transportation from Karachi to the borders.

iv) Information on the requirements for bonded warehouses.

v) Existing transit facilities provided by the GOP for the Afghan Government.

vi) Recommendations.

vii) Any other information requested by the COP.

\section{on Agricultural Machinery and Equipment}

i) Overall regulatory environment.

ii) Possible financial mechanisms available for purchasing the equipment.

iii) Description of the variety of available LCs and the steps involved in opening an LC.

iv) Possible dealership networks extending into Afghanistan.

v) Incentives required to stimulate manufacturers.

vi) Warehousing arrangements.

vii) Insurance types and mechanisms aimed to lower the risk of Pakistani manufacturers.

viii) Recommendations.

ix) Any other information requested by the coP. 


\section{Correspondence between EDC and CBR}

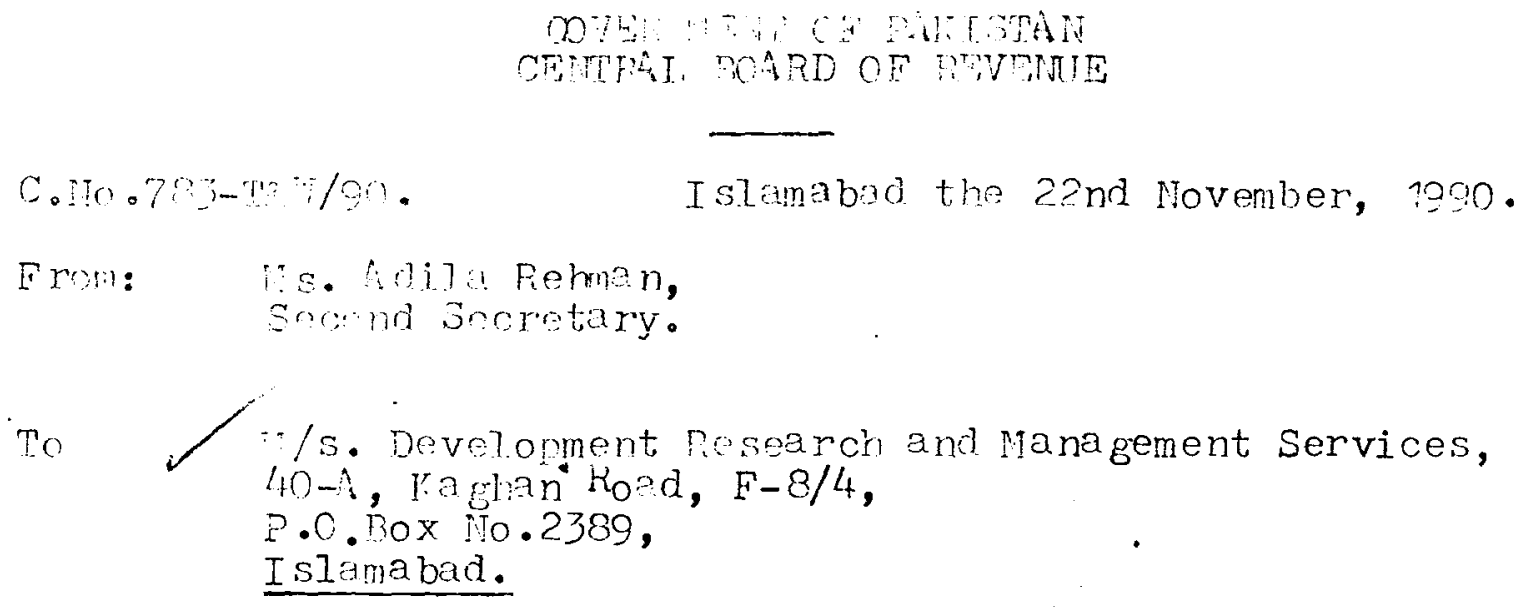

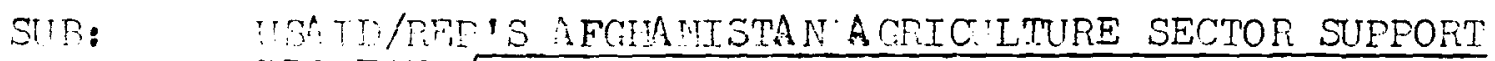
DPOUTCE.

Finily refer to your letter No. nil doted 31.10.1990. You are reanonter to appear personally in connection with certin cl-rifichinns reguiged regording the subject project.

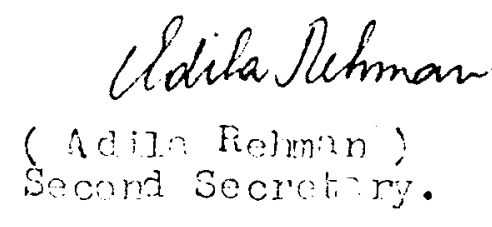




\section{DLLIJ 1 ('vt.) Limited}

Development Reseatch and Management Services

- 40-A. Kaglaan Rual. F.R/A, Y.(1. Hox 2389, Islamahal, Pakislan.

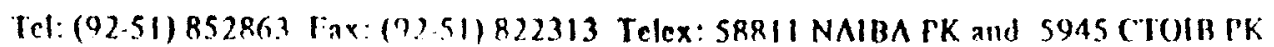

October 31,1990

The Member customa

Central Board of Revenue

Is 1 amabart

Subject: UBnID/Rep's Afghanistan Agriculture sector support projeot

sir,

The United states Agency for International Development's Representative office for Afghanistan ( $A I D / R e p)$ plans to initiate varlous steps to facllitate trade between $\Lambda$ fghanistan and pakistan under the above mentioned project. To begin with, the following two major activities are proposed:

1. Import of approximately 22,000 to 25,000 metric tonnes of DAP fertilizer funded by the profect and a consortium of Afghan traders into Pakistan; storage in warehouses at the Pakistan - Afghanistan borders in Baluchistan and N.W.F.P; and, subsequently marketed (sold) In $\lambda$ fghanlstan through dealers across the borders.

2. Facilitation of export of agricultural farm machinery and tractors manufactured/assembled in pakistan to $\lambda$ fghanistan. The proposed arrangement is to have the products (tractors and other machinery) for display in various border sales depots, from where they will be marketed into Afghanistan through Afghan dealership networks.

We, as consultants to the main contractor of the project, would be grateful if you can very kindly provide us the regulations of the Government of paklstan governing the above issues, and highlight the rules (if there are any) which would prohibit such transactions.

We greatly appreclate your cooperation in this regard.

Thanking you, I remain,

Yours fajthrully,

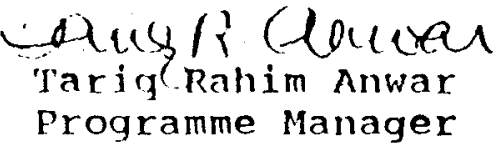




\title{
LEGAL ANNEX
}

$3^{0}$

\author{
RELEVANT EXTRACTS \\ from \\ THE CUSTOMS ACT, 1969 \\ by \\ NAJIB A. CHOUDHRY
}

CHAPTER III: DECLARATION OF PORTS, AIRPORTS, LAND CUSTOMS-STATIONS, ETC.

CHAPTER XI: WAREHOUSING

CHAPTER XII: TRANSHIPMENT

CHAPTER XIII: $\quad$ TRANSIT TRADE 


\section{CHAPTER III}

\section{DECLARATION OF PORTS, AIR- PORTS, LAND CUSTOMS- STATIONS, ETC.}

9 Declaration of customs-ports, customs-airports, etc.-- $T$ ie Board may, by notification in the official Gazette, declare--;

${ }^{1}$ [(a) the places which alone shall be customs-ports ir customs-airports for the clearance of goods or any class of goods imported or to be exported; ]

(b) the places which alone shall be land custorr ;stations for the clearance of goods or any class if goods imported or to be exported by land ir inland waterways;

(c) the routes by which alone goods or any class if goods specified in the notification may pass : $y$ land or inland waterways into or out of Pakista !, or to or from any land customs station or to $\mathrm{r}$. from any land frontier;

(d) the places which alone shall be ports for th : carrying on of coastal trade with any specific ! customs-ports in Pakistan; and

(e) what shall for the purposes of this" Act $b$ : *1,.... deemed to be a customs-house and the limi ; thereof.

\section{Legal Reference}

1.: : Substituted for the original clause (a) by the Finance Act, 1973. The original clat . (a) was as under:-

(a) The ports and airports which alone shall be custonts ports or custor aliports for the unloading of imported goods and loading of goods ter export or any class of such goods;". 
PTCL. 1987 St. 204 or see page 612 of the Customs Rules and Notifications, 1970-89 by Najib A. Choudhry - An allied publication.

, 91 Specification of llimita of Customs Nir Port, Lahore,-See Notification Na. S.R.O. 1135(I)/8G dated 304h December, 1986, reported as PTCL 1987 St. 205(i).

(11) Power to declare warehousing stations.--The Board may, by notification in the official Gazette, declare places to be warehousing stätions at which alone public warehouses may be appointed and private warehouses may be licensed.

,

This section corresponds to Section 14 of the Sea Customs Act. This section now permits establishment of warchouses in the inicrior and at Land Customs-station, thus extending warchousing facilitics in the intcrior and also in respect of the goods imported by land.

in Warehousing Stations.--The Central Board of Revenue under Notification No. S.R.O 111(I)/83, dated 12th February, 1983 as amended from time to time has declared the following places to be warehousing stations at which alone public or private warehouses can be appointed or licensed, as the case may be.-

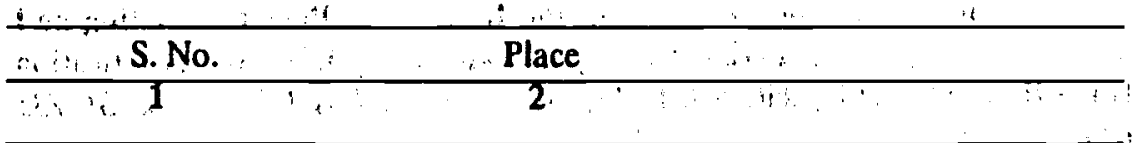

$\begin{array}{lll}\text { A. } & \text { Karachi Division. } \\ & \text { 2. Gaddani (District Lasbella) }\end{array}$

B. $1 ., 1$, Hyderabad City (Municipal Limits and Hyderabad

$\therefore, \quad:,,$, , Cantonment)

2. Kotri Taluka (District Dadu).

3. District Sukkar

4. District Thatla.

atenten 5 District Dadu.

6. $\because$ District Badin.

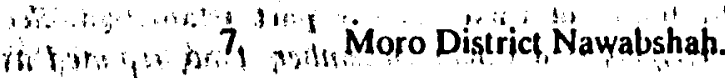




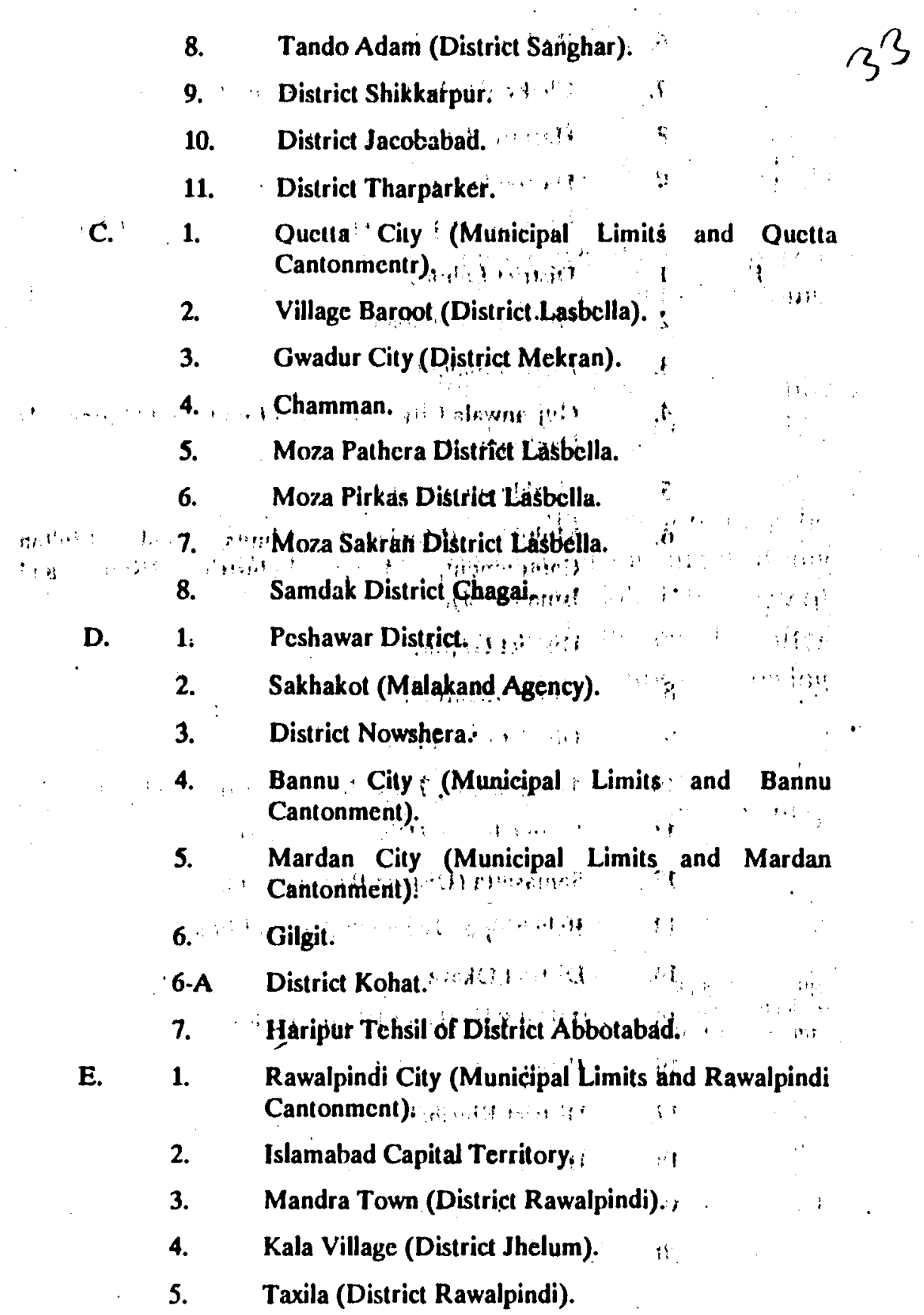




\section{$3^{4}$ CHAPTER XI WAREHOUSING}

84 Application to warehouse.--When any; dutiable goods have been entered for warehousing and assessed under section 80, the owner of such goods may apply for leave to deposit the same in any warehouse appointed or licensed under this Act ${ }^{1}[$ :

Provided that the Collector of Customs, for reasons to be recorded in writing, nlay disallow the warehousing of goods or any class of goods or goods belonging to a particular importer.]

\section{Legal Keference}

d. Substituted for the full stop and thereafier the proviso added by the finance Aat, IXX), with effect Irom lst July, 1900.

\section{NOTES}

General.-.But for the substitution of the corresponding section, this section is verbatim reproduction of Section 90 of the Sea Customs Acl, 1878. The proviso is added by the Finance Act, 1\%). II empowers the Collector to disallow the warchousing of goods or any class of goods belonging to a parlicular importer. The order of disallowing must be recorded in writing alter stating the reasons for disallowing such warchousing.

Warehousing Schene. - In England in 1803 what is in effect the existing warehousing scheme was introduced. It was said of it that besides mecting the axiom that a tax, as far as possible, ought to be levied at the tine and in the manner most convenient for its payment--il obviated forced sale of imported goods, broke down monopolies and augmented the carrying Irade of the counlry.

A warchousing system also--

(1) allows an importer to avoid-.

(a) a lock up of capital (in the shape of duty) until he wants the goods for home markel, and

(b) paying duty at all on goods for which he finds an export market;

(2) permits greater stocks of goods to be carried in the country because the duty has not to be paid inmediately, with a 
Warchousing facilities under the present $\mathbf{A c t}$, are available at warehousing-stations which are declared by the Central Board of Revenue as warchousing stations under Section 11. Under the old law warchousing was allowed at ports which were declared as warchousing ports under Section 14 of the Sea Customs Act. Under the ncw Act it is permissible to cstablish of warchouses in the interior of the country and at land Customs Stations thus extending warchousing facilities in the interior and also in respect of the : goods imporled by land or air. For warchousing stations see Notes under Scclion 11.

Classes of warelsouses.--Warchouses are of two kinds, namcly public warchouses and privale warchouses.

Warehousing stations.--See Notes under Section 11.

To entitle to the protection, procedure has to be followed.--Seclions 90 to 96 of the Sca Customs Act (now Sections 84 to 90) prescribe the procedure for warchousing of goods. The object of the Legislature in providing for the licensed warchouses was 10 give protection to the owner in certain cases and to entitle himself to this protection, the owner has to follow the procedure laid down for the purpose. The owner has to make an application under Section 90 (now. the present section) for storage in a licensed warchouse after goods have been assessed to customs duty (51) J.L.R. (1951) I Cal. 443).

Rules for bonding ut warehousiing stations of un-manufactured foreign Tobucco imported and intended to hone consumption for the manufucture of Cigarettes, Cigars and imanufuctured Tobacco.--See Notification No. S.R.O. 123 (1)/83, dated 12th February, 1983 reponed as PTCL 1983 St. 343 or page 408 of the Customs Rules and Notifications, 1970S9 by Najib $A$. Choudlin' - An allicd mublicarion.

\section{Form of application.--Every such application shall be in writing signed by the applicant, and shall be in such form as may be prescribed by the Board.}

\section{NOTES}

General..-This section is a reproduction of Section 91 of the Scá Customs Act, 1878.

Forın of application for leave to deposit goods in a wareliouse.-.For Form. (Sce Notification No. S.R.O. 263(I)/70, dated 29th October, 1970 reproduced at page 36 of the Customs Rules. and Notifications, 1970-89 by Najib A. Chondliny - An allied publicution). 
$\therefore$

86 Warehousing bond:--(1) When any such application has been made in respect of any goods, the owner of the goods to which it relates shall execute a bond, binding himself in a penalty of twice the amount of the duty assessed under Section 80 or Section 81 or reassessed under Section 109 on such goods,--

(a) to observe all the provisions of this Act and the rules in respect of such goods;

(b) to pay on or before a date specified in a notice of demand all duties, rent and charges payable in respect of such goods together with '[surcharge] on the same from the date so specified at the rate of ${ }^{2}$ [two percent per month] or such other rate as is for the time being fixed by the Board; and

(c) to discharge all penalties incurred for violation of the provisions of this Act and the rules in respect of such goods.

(2) Every such bond shall be in such form as is from time to time prescribed by the Board, and shall relate to the goods or portion of the goods of one conveyance only.

(3) Notwithstanding anything in sub-section (2), for the purposes of sub-section (1), the Collector of Customs may permit any importer to enter into a general bond in such amount and subject to such conditions, limitations or restrictions as the Collector of Customs may determine in respect of the warehousing of goods to be imported by such importer within a specified period.

(4) A bond executed under this section by an importer in respect of any goods shall continue in force notwithstanding the transfer of the goods to any other person or the removal of the goods to another warehouse or 
warehousing station:

Provided that, where the whole of the $e^{i}$ goods or any part thereof are transferred to another person, the appropriate officer may accept a fresh bond from the transferee in a sum equal to twice the amount of duty assessed on the goods transferred and thereupon the bond executed by the transferor shall be deemed to be discharged to the extent to which the fresh bond has been executed by the transferee.

\section{Legal References}

1. "Substiluted for the word "interest" by the finance Act, 1900 with effect from Ist July, 1900

2. Substituled for the words "eight percent per annum" by the Finance Ordinance, 1981 with effect from 25 ih June. 1981.

\section{NOTES}

General.--This section corresponds to Scctions 92 and 109 of. the Sea Customs Act with the following amendments:--

(i) Provisions have been made to obtain bond equai to twice the amount of duty as assessed or reassessed provisionally.

(ii) The rate of interest (now surcharge) has been increased to eight percent from six percent per anntm. (Now the rate of interest is $2 \%$ per month with cffect from 25th Jine, 1981).

(iii) . It will apply to all conveyances.

(iv) Penalties will also be covered by the bond.

(v) Under the old law there was no provision for permitung the warehousing of goods imported by land. Under the new provision goods imported by land will also be allowed to be warehoused.

(vi) Sub-section (3) is new provision which will enable an importer to enter into a general bond for the warehousing of goods to be imported by him within a specified future period.

(vii) It has been specifically provided thall even if the goods are transferred to another person, the bond executed by the importer shall remain in force, but if the transferee executes a fresh bond in respect of the goods purchased by him, the bond execuled by the transferor shall be deemed to be 
discharged to the extent to which ihe fresh bond is executed by the transferee.

(viii) The rate of eight percent further changed to $2 \%$ per month by the Finance Ordinance, 1981.

Appropriate Ollicer.--The Assistant Collector of Customs has beed assigned the functions of the "appropriate officer" to act under this section. (See Notificution No. S.R.O. 806(I)/84, dated 201/1 Seplember, 1984 reponed as PTCL 1985 St. 25 or page 909 of the Customs Rules and Notifications, 1970. So by Najib A. Choudling - An allicd publication).

Course of inport when ends.--The customs fronticr is only a notional barrier. When once the goods have been landed at a customs port and have been subjecled to tax in the sense that levy of tax has been made thereon even though the gexods might not have been cleared for home consumption, it can be said that the goods might not have ceased to be part of the import stream and have notionally crossed the customs frontier. There is, therefore, no objection to the goods being brought into the country and mere fact that the importer for the purpose of his own convenience warehouses the goods and thereby postpones the payment of the duty levied on the goods cannot be taken to indicate that the goods are still beyond the customs frontier (AIR $\left.1962 \mathrm{Mad} .29 \AA^{\prime}\right)$.

Act.

Procedure on failure to pay duty.--See Section 112 of the Customs

Place of execution of bond..."Under Rulc 1 of S.R.O. 69(I)/70, dated the 17th April, 1970, the importer is required to execute a bond to clear the raw material without payment of duty and the Board has prescribed a bond form vide S.R.O. 131(I)/71, dated the 20th April, 1971. A doubt has arisen about the place where the bond is 10 be filed and the officer by whom the same is to be accepled.

2. Board's ruling contained in letter C.No.4 (IMP) L\&P/71, dated 11th April, 1972 is reproduced below:--

"The Collector of Customs at the port of entry of the goods should accept the bond as he would be the first officer to entertain as into Bond Bill of Entry. He should, however, send an allested copy of the bond accepted by him 10 the Collector of Customs in whose jurisdiclion the goods are actually to be stored in a bonded warchouse and, therefore, both the Collectors should keep on informing each other about the clearances of the goods from time to time so that the entire process remains under constant watch of both". (Customs General Order No: 13 of 1973 issucd by C.B.R.). 
For Nolifications referred to in the General Order see pages 12 and 63 of the Customs Rules and Notifications, 1970-89 by Najib A. Choudhry - An allied publication.

Form of bond.--For Form see Notification No. S.R.O. 13I(I)/7I, dated the 20kh April, 1971 riproduced at page 63 of the Customs Rules and Nonifica.:ons, 1970-89 by Najib A. Choudhry - An allicd publication.

Rules for the manulacture of Cigareltes or Tobacco in bond from munufuctured foreign Tobacco imported and warehoused.--Sec Notification No. S.R.O. 124(I)/83, daled 12 h February, 1983 (reponed as PTCL 1983 St. 346 or page 412 of the Customs Rules and Notifications, 1970-89 by Najib $A$. Choudliny - An allied publication).

87. Forwarding of goods to warehouse.-.(1) When the provisions of Sections 85 and 86 . have been complied with in respect of any goods, such goods shall be forwarded in charge of an officer of customs to the warehouse in which they are to be deposited.

(2) A pass shall be sent with the goods specifying the name of the bonder and the name or number of the importing conveyance, the marks, numbers and contents of each package, and the warehouse or place in the warehouse wherein they are to be deposited.

\section{NOTES}

Generul.--This scction corresponds to Section 93 of the Sca Customs Acl with slight modifications such as dividing the section into two subsections and specifying the name or number of the importing conveyance. Acl.

Olfences and penalties.--Sce clause (49) of Section 156 (1) of the

88 Receipt of goods at warehouse.-.-(1) On receipt of the goods, the pass shall be examined by the warehouse-keeper, and shall be returned to the appropriate officer.

(2) No package, butt, cask or other container shall be admitted into any warehouse unless it bears the marks and 
[Secs. 88-90]

numbers specified in, and otherwise corresponds with, the pass for its admission.

(3) If the goods be found to correspond with the pass, the warehouse-keeper shall certify to that effect on the pass, and the warehousing of such goods shall be deemed to have been completed.

(4) If the goods do not so corresponds, the fact shall be reported by the warehouse-keeper for the orders of the appropriate officer, and the goods shall either be returned to the custom-house in charge of an officer of c!lurms or kept in deposit pending such orders as the warehouse-keeper deems most convenient.

(5) If the quantity or value of any goods has been incorrectly stated in the bill of entry, due to inadvertence or bona fide error, the error may be rectified at any time before the warehousing of the goods is completed, and not subsequently.

\section{NOTES}

General..-The corresponding section of the Sea Customs Act is 94 . This section has been divided into 5 sub-sections. Sub-section (5) specifically provides for the rectification of the quantity or value of any goods incorrectly stated in the bill of entry only duc to inadvertence or bona fide crror.

Amendment of the receipt of goods not permissable..-Also sce Section 205 of the Act. However rectification is allowable.

Appropriate Omicer...The Central Buard of Revenue has assigned the functions of the "appropriate oflicer" under this section to the following officers of customs, namcly.-

(i) Inspector/Preventive Oificer/Examiner for the purpose of sub-section (1); and

(ii) Deputy Superintendent/Inspector, Preventive Service/ Appraiser for the purpose of sub-section (4).

(See Notification No. S.R.O. $806(I) / 84$, dated 20th September, 1984, reporied as PTCL 1985 St. 25 or page 909 of the Custoinis Rules and. Notifications, 1970-89 by Najib A. Cliond/ny - An allied publication). 
- Ofrences and penalties..-Sce clause (50) of Section 15ל(1) of the Act.

89 Goods how warehoused.-. Except as provided in section 94, all goods shall be warehoused in the packages, butts, casks or other containers in which they have been imported.

\section{NOTES}

General.--This section is reproduction of Section 95 of the Sea Customs Acl. 94 infra.

Owner's powers to deal with goods to be warehoused..-Sec Section

90 Warrant to be given when goods are warehoused.--(1) Whenever any goods are lodged in a public warehouse or a licensed private warehouse, the warehouse-keeper shall deliver a warrant signed by him as such to the person lodging the goods.

(2) Such warrant shall be in such form as the Board may from time to time prescribe, and shall be transferable by endorsement; and the endorsee shall be entitled to receive the goods specified in such warrant on the same terms as those on which the person who originally lodged the goods would have been entitled to receive the same.

(3) The Board may, by notification in the official Gazette, exempt any class of goods from the operation of this section.

\section{NOTES}

General.--This section replaces Section 96 of the Sea Customs Act. The section has been divided into threc sub-sections. Sub-scclion. (3) empowers the Central Board of Revenuc to exempt any class of goods from the operation of this section. Under the old law the provisions were only for salt and salted fish. 
91 Access of customs officer to private warehouse.--The appropriate officer shall have access to any private warehouse licenşed under this Act.

\section{NOTES}

General..-This section embodics the same provisions as existed in Section 97 of the Sca Customs Act. It provides to the Customs Officer access to any private warchouse licensed under the Acl.

Searcli warrant.--No warrant is needed for such access.

Appropriate Onicer.--The Central Board of Revenuc has assigned the functions of the "appropriate oflicer" under this section to Inspector/Preventive Orficer/Examiner of Customs. (Sice Notification No. S.R.O. $806(1) / 84$, dated 20h S(ptember, 1984, reponcal as PTCL 1985 St. 25 of page 909 of the Citstoms Rules and Notifications, 1970-89) by Najib $A$. Choudhry - An allical publicarion).

Entrustment of the functions of the oflicers of Custons to the Orticers of the Valuation.--The Central Board of Revenue has appointed in relation to the area of their posting the Valuation Officers, Appraisers, Principal Appraisers, Assistant Controllers, Deputy Controller and Controller, of Customs Valuation with said designation and has cntrusted to them, subject to the Rules made under the Customs Act, the functions of an officer of Customs under Section 91 of the Customs Acl, 1969. (Set Notification No. S.R.O. $109(1) / 82$, reproduced at page 3.32 of the Customs Rule's and Notifications, 1970-8'9 by Najib A. Choud/hy - An allied publicalion).

Entrustment of functions of the Orlicers of Custons to the Onlicers of the Directorate of Inspection.-.The Central Board of Revenue has authorised the Director, Deputy Dircctor, Assistant Dircctors, Principal Survey Officer and Survey Officer of the Directorale of Inspection (Customs and Central Excise) to excrcise the powers and discharge the duties of the officers of Customs under Section 91 of the Custonis Act, 1969. (See Notification No. S.R.O. $72.3(1) / 84=$ PTCL 1985 St. 19 or page 517 of the Customs Rules and Notifications, 1970-89 by Najib A. Choudhy' - An allicd publication).

Power of the Ollicers of the Directorale of lintelligence and Investigation (Customs and Excise)...The Intelligence Officers, Senior Intelligence Officers, Principal Appraisers, Appraisers, Superintendents, Assistant Directors, Deputy, Directors, Director, Dircctor Gericral of the Directorate of Intelligence and Investigation (Customs and Excise) have been authorised to exercise powers and discharge dulies of the Officers of Custom 
under the provisions of Section 91 of the Customs Act within their respective jurisdiction. (Sec Norification No. S.R.O. 38\$(I)/\$2, reproduced at page 339 of the Customs Rules and Notifications, 1970-89 by Najib A. Choudhry - An - allicd publication).

Orrences and penalties.--See clausc (52) of Section 156(1) of the Act.

92 Power to cause packages lodged in warehouse to be opened and examined.--(1) The appropriate officer may at any time by order in writing direct that any goods or packages lodged in any warehouse shall be opened, weighed or otherwise examined; and, after any goods have been so opened, weighed or examined, may cause the same to be sealed or marked in such manner as he thinks fit.

(2) When any goods have been so sealed and marked after examination, they shall not be again opened without the permission of the appropriate officer; and, when any such goods have been opened with such permission, the packages shall, if he thinks fit, be again sealed or marked.

\section{NOTES}

General.--This section corresponds to Section 98 of the Sea Customs Act.

Appropriate Oflicer.--The Central Board of Revenue has assigned the function of the "appropriatc officer" under this section to Inspector/ Preventive Officer/Examiner of Customs. (See Notification No. S.R.O. 806(I)/84, dated 20kh Scptember, 1984, reponted as PTCL 1985 St. 25 or page 909 of the Customs Rules and Notifications, 1970-89 by Najib A. Choudhry An allied publication).

Entrustment of the functions of the oflicers of Customs to the Ollicers of the Valuation.--The Central Board of Revenue has appointed in relation to the area of their posting the Valuation Officcers, Appraisers, Principal Appraisers, Assistant Controllers, Deputy Controller and Controller of Cusioms Valuation with said designation and has contrusted lo them, subject to he Rules made under the Customs Acl, the functions of an officer of Custoine under Section 92 of the Customs Act, 196\%). (See Notification No. S.R.O. 199(I)/82, reproduced at page 3.32 of the Customs 
Rules and Norifications, 1970-89 by Najib A. Choudhry - An allied publication).

Entrustment of functions of the Oflicers of Customs to the Onicers of the Directorate of Inspection...The Central Board of Revenue has authorised the Director, Depuly Director, Assistant Directors, Principal Survey Officer and Survey Officer of the Directorate of Inspection (Customs and Central Excise) to exercise the powers and discharge the duties of the officers of Customs under Scction 92 of the Customs Act, 1969. (See Nolification No. S.R.O. $723(1) / 84=$ PTCL 1985 St. 19 or pagc 517 of the Customs Rules and Notifications, 1970-89 by Najib A. Choudhn' - An allied publication).

Powers of the Ollicers of the Directorate of Intelligence and Investigation (Customs and Excise).--The Intelligence Olficers, Senior Intelligence Officers, Principal Appraisers, Appraisers, Superintendents, Assistant Directors, Deputy, Directors, Director, Director General of the Directorate of Intelligence and Investigation (Customs and Excise) have been authorised to exercise powers and discharge duties of the Officers of Customs under the provisions of Section 92 of the Customs Act within their respective jurisdiction. (Sece Notification No. S.R.O. 38\%(I)/82, reproduced at page 339 of the Customs Rules and Notifications, 1970-8'. by Najib $A$. Choudliny - All allied publication).

Act.

Oflences and penalties...Sece flause (55) of Section 156 (1) of the

93 Access of owners to warehoused goods.--(1) Any owner of goods lodged in a warehouse shall, at any time within the hours of business, have access to his goods in the presence of an officer of customs, and an officer of customs shall, upon application for the purpose being made in writing to the appropriate officer, be deputed to accompany such owner.

(2) When an officer of customs is specially employed to accompany such owner, a sum sufficient to meet the expense thereby incurred shall, subject to rules, be paid by such owner to the appropriate officer, and such sum shall, if the appropriate officer so directs, be paid in advance. 


\section{NOTES}

General.--This section sulstantially embodics the provisions of Section 9 ) of the Sca Customs Act.

Appropriate Ollicer..-The Depuly Superintendent/Inspector, Preventive Service/Appraiser of Customs has assigned the lunctions of the "appropriate officer" under this section. (See Notification No. S.R.O. 806(I)/84, dated 20th September, 1984, reported as PTCL 1985 St. 25 or page 909 of the Customs Rules and Notifications, 1970-89 by Najib A. Choudhry An allied publicution.

Ofrences and penalties.--Sec clause (54) of Section 156(1) of the Act.

94 Owners' power to deal with warehoused goods.--(1) With the sanction of the appropriate officer and on payment of such fees as may be prescribed by rules, the owner of any goods may, either before or after warehousing the same,--

(a) separate damaged or deteriorated goods from the rest;

(b) sort the goods or change their containers for the purpose of preservation, sale, export or disposal of the goods;

(c) deal with the goods and their containers in such manner as may be necessary to prevent loss or deterioration or damage to the goods;

(d) show the goods for sale; or

(e) take such samples of goods as may be allowed by the appropriate officer with or without entry for home-consumption, and with or without payment of duty, except such as may eventually become payable on a deficiency of the original quantity.

(2) After any such goods have been so separated and repacked in proper or approved packages, the appropriate dficer may, at the request of the owner of such goods, cause or 
permit any refuse, damaged or surplus goods remaining after such separation or repacking (or, at the like request, any gooth which maly not be worth the duty) to be destroyed, and maj remit the duty payable thereon.

\section{NOTES}

General.--This scetion corresponds to section 100 of the Su Customs Act. Clause (d) in sub-scction (1) is a new provision which permity the bonder to show his goods for salc to buyers.

Goods how warehoused.--Sce Scction 89 silpra.

Furtler processes of the goods in a warehouse.--Sec Section of illfra.

Appropriate (Olicer.:-The ('intral Buard al Revenue hats assignted the funclions of the "approprialle olficer" (o) the following ollicers of cusloms namely.-

(i) Superintendent/Principal Appraiser of Customs for the purposc of sub-section (1); and

(ii) Assistant Collectur of Custons for the purpose of subsection (2).

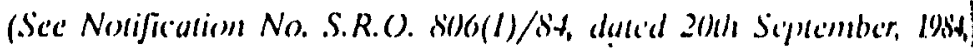
reponted as PTCL 108.5 Si. 2.5 or page o(1) of the Customs Rules and Notifications, 197()-80) by Najib A. (houdhyy - All allical publication).

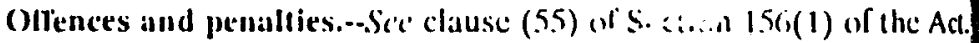

95 Manufacture and other operations in relation to goods in a warehouse.--(1) Subjec. (o) rules, the owner of any warehoused goods may, with the permission in writing of the Collector of Customs, carry on any manufacturing process or other operations in the warelouse in relation to such goods.

(2) Where in the course of any such operation or process there is any waste or refuse the following provisions shall apply, namely:--

(a) If the whole or any part of the goods produced by such ineration or process are exported, no 
duty shall be charged on the quantity of the warehoused goods wasted or turned into refuse in the course of the operation or processing carried on in relation to the goods exported:

Provided that such waste or refuse is either destroyed or duty is paid on such waste or refuse as if it had been imported into Pakistan in that form.

(b) If the whole or any part of the goods produced by such operation or process are cleared from the warehouse for home-consumption, duty shall be charged on the quantity of the warehoused goods wasted or turned into refuse in the course of the operation or processing carried on or in relation to the goods cleared for home consumption.

\section{NOTES}

General.--Il is a new provision. It permits manufacturing processes and other operations to be carricd on in a bonded warehouse. It also provides for the waiver of duty in respect of such portion of the goods as are converted into refuse or waste in the course of manufacture ar processing, if final products are exported. If however, such products are cheared for homeconsumption; tuty shall not be waived. This has been provided because refuse in manufacture is not a loss to the manufacturer. While calculating the cost of production, he adds the cost of wasted materials. And if the product is consumed in Pakistan, there is no reason why duty should not be paid on the wasted products.

96 Payment of rent and warehouse dues.--(1) If goods be lodged in public warehouse, the owner shall ' [unless exempted by an order of the Collector or an officer not below the rank of Assistant Collector authorised by him] pay monthly, rent and warehouse-dues at such rates as the Collector of Customs may fix. 
(2) A table of the rates of rent and warehouse-dues so fixed shall be placed in a conspicuous part of such warehouse.

(3) If any demand for such rent or dues is not discharged within ten days of its presentation, the appropriate officer may, in the discharge of such demand (any transfer or assignment of the goods notwithstanding) cause to be sold, after due notice in the official Gazette, such sufficient portion of the goods as he may select.

(4) The proceeds of such sale shall be adjusted in accordance with section 201.

\section{Legal Reference}

1. Inserted by the Finance $A \mathrm{Cl}, 1973$.

\section{NO'TES}

General.--This section corresponds to Seclion 101 of the Sea Customs Act. The provision regarding the adjustment of the sale proceeds of goods has been omilled from this section as it has becen incorporated in Section 201 of the present Act.

Appropriate Olficer.-.The Assistant Collector of Customs has been assigned the functions of the "appropriate officer":--

(i) In act under this section; and

(ii) to extend the time for discharging demand of rent or dues under sub-section (3).

(See Nonifiation No. S.R.O. $806(1) / 84$, daled 20th September, 1984 reponed as PTCL 1985 St. 25 or page 909 of the Customs Rules and Notifications, 1970-89 by Najib A. Choudhry - An allicd publication).

Goods not stored in warehouse..- Where the goods were not stored in any warehouse but were kept in the District Treasury and then in the Divisional office of the Customs Department for safe custudy, charges for storage and up keeps of the same could not have been levied on the person from whose premises they were seiacd (1980 CR. LJ S4 (Indian case).

Rates of warehouse storage fee at Lahore.-See Notifications Nos. S.R.O. 1247(I)/82 and 1248(I)/82, (reported as PTCL 1983 St. 292 and PTCL 1983 St. 293 respectwely or pages 353 and 354 of the Customs Rules and 
Nolifications, $1970-89$ by Najib $A$. Choudhry - An allied publication).

Storage fee for goods for depositing in the State Warehouse of Rawalpindi Collectorate of Customs.--For see Notification No. S.R.O. 1079(1)/86, daled 24th November, 1986 (reported as PTCL 1987 St. 158 or page 608 of the Customs Rules and Notifications, 1970-89 by Najib $A$. (houdhny--An allicd publication).

Storage Fee for goods for depositng in certain units in the Customs Collectorate of Rawalpindi.--See Norification No. S.R.O. $1080(1) / 86$ dated 2th November, 1986 reponed as PTCL 1987 St. IS9(i) or page 609 of the Customs Rules and Notifications, 1970-89 by Najib A. Choudliny - An allied publication.

97 Goods not to be taken out of warehouse except as provided by this Act.--No warehoused goods shall be taken out of any warehouse, except on clearance for home-consumption or export, or for removal to another warehouse, or as otherwise provided in this Act.

\section{NOTES}

General.-This section substantially embodies the provisions of Section 102 of the Sea Customs Act.

Removal of Cinematograph from a warehouse films for test.-.The Government has authorised, as an experimental measure, the arrangenient under which cinema films may be removed from a warehouse to a studio for lest subject to the following precautions:

(i) The risk of loss and damage in transit and at the time of examination is covered by the bond under Section 86;

(ii) The films are removed and brought back under customs escort and at the bonder's expense; and

(iii) The examination should be held under customs supervision.

(See page 195 of General Mamual of Orders : Edition 1964).

1998 Period for which goods may remain warehoused.-.(1) Warehoused goods, other than consumer goods notified by the Central Board of Revenue, may remain in the warehouse for a period of six months following the date of their admission into the warehouse and consumer goods so notified may remain in the warehouse for a period of three months following the said dale: 
Provided that the said period may, in case of nonperishable goods, be extended, on sufficient cause being shown by the owner of the warehoused goods and subject to the condition that he pays in advance surcharge on the duty and taxes involved at two per cent per month for the extended period,--

(a) by the Collector of Customs, for a period not exceeding six months; and

(b) by the Federal Government or the Board, for such period as it may deem fit.

(2) The Federal Government may, subject to such conditions or restrictions as it may deem fit to impose, by notification in the official Gazette, remit the whole or a part of the surcharge in case of any goods or category of goods and the Board, in circumstances of exceptional nature, may, subject to such conditions, limitations or restrictions, if any, as it may think fit to impose, by a special order in each case recording such circumstances, remit the whole or a part of the surcharge.

(3) Notwithstanding anything contained in sub. section (1), the Federal Government may, by notification in the official Gazette, limit the period for which any consumer goods or class of consumer goods may remain in the warehouse:

Provided that such period shall not be less than one month.

(4) When the licence of any warehouse is cancelled, the owner of any goods warehoused therein shall, within ten days of the date on which notice of such cancellation is given, or within such extended period as the appropriate officer may allow, remove the goods from that warehouse to another warehouse or clear them for home-consumption or exportation.] 


\section{Legal References}

Section 98 substituted by the Finance Act, 1990 Section 98 at the ine of sulbstitution was as under:-

1-198 Period for which goods may remain warehoused...Any warchoused gou.ds may remain in the warehouse for a tolal period of one year following the date of the execution of the bond under Section 86 in respect of them:

Provided that-

${ }^{\text {Ib }}$ (i) the said period may, in case of non-perishable goods, be extended, on sufficient cause being shown by the owner of the warehoused goods and subject to the condition that he pays in advance interest on the duty involved at two percent per month for the extended period;-

(a) by the Collecior of Custonis-for a period not exceeding one year; and

(b) by the Board--for such period as it may deem fit:

Provided further that in circumstances of exceptional nature, the Board may, subject to such conditions, limitations or restrictions, if any, as it may think fit to impose, by a special order in each case recording such circumstances, remit the whole or a part of the interest;

(ii) when the licence of any private warehouse is cancelled, the owner of any goods wa rehoused therein shall, within ten day's of the date on which notice of such cancellation is given or within such extended period as the appropriate officer may allow, remove the goods from that warehouse to another warehouse or clear them for home-consuniption or exportation.]

Section 98 substituted by the Finance Ordinance, 1979. Prior to the substitution Section 98 rans as under.

"98 Period for which goods may remain warehoused...Any warehoused goods may remain in the warehouses for a total period of three years following the date of the execulion of the bond under Section 86 in respect of them:

Provided that-

(i) in the case of any goods which a re likely to deteriorate, the said period of three years may be reduced by the Collector of Customs to such reasonable period as he diems fil in each case;

(ii) in the case of any goods which are not likely to deteriorate, the period of three years may, on sufficient cause being shown, be extended by the Collector of Customs by a period not exceeding one year and by the bond by such further period as it may deem fit;

(iii) When the licence of any private warehouse is cancelled, the owner of any goods warehoused therein shall within ten days of the date on which notice of such cancellation is given or within such extended period as the appropriate officer may allow, remove the goods from that warehouse to another warehouse 
Or cicar them for home-consumption or exportation."

1-b. Clause (i) substituted by the I-inance Ordinance, 1982. Previously the clause (i) was as under,-

"(i) the suid period may, on sufficient cause being shown, be extended by the Board by such period as it may deem fit ; and

\section{NO'TES}

Generul...This section corresponds to Section 103 of the Sea Customs Act with the following amendments:--

(i) Proviso (i) permits the Collector of Customs to reduce the normal warehousing period of three years where the goods are likely to deteriorate. This change has been made to safeguard revenue.

(ii) Proviso (ii) permits the extension of warehousing period of one year by the Collector of Customs and for further period by the Central Board of Revenue.

(iii) Proviso (iii) provides a period of ten days or extended for removal of the goods, from the date on which notice is given. Under the old law the period was only seven days.

(iv) Proviso regarding salt warehoused in a public or private warehouse has been omitled.

Appropriate Ofricer.--The Deputy Collector of Customs has been assigned the function of the "appropriate officer" to act under this section. (See Notification No. S.R.O. 806(I)/84, dated 20th September, 1984, reponted as PTCL 1985 St. 25 or page 909 of the Customs Rules and Notifications, 1970. 89 by Najib A. Choudhry - An allied publication).

\section{DEPARTMENTAL INSTRUCTION}

Time limit of Section 32 also applicable to charge.--Provisions of sub-section 32(2) and (3) regarding limitation are also applicable to charge leviable under Section 111 read with Section 98 (PTCL 1989 CL. 60).

Amendment in Section 98 curtailing the time limit is prospective.. Amendment in Section 98 has prospective effect and not retrospective effect. The amount of surcharge under Section 98 for the period prior to the commencement of the amendment curtailing warehousing period cannot be charged (PTCL 1989 CL 60).

Consumer goods for which warehousing period is $\mathbf{3 0}$ days.--The Federal Government has fixed the warehousing period of 30) days for certaio 
items falling under heading No. 1507, by Notification No. 176(1)/87. (For Original Notification see Customs Rule's and Notifications, 1970-89, page No. 618).

Consumer goods for which warehousing period is 3 months...The Federal Government has fixed the warehousing period for sugar falling under sub-headings $1701.1100,1701.1200,1701.9100$ and 1701.9900 of the Customs Tariff as three months vide Notification No. 536(1)/88, dated 26th June, 1988. (For Original Notification see Customs Rules and Notifications, 1970-89 paje, No. 761).

Consumer goods for which warehousing period is Three montlis..The Federal Government has issued Notification No. S.R.O. 495(I)/88, dated 26th June, 1988. (For Original Notification see Customs Rules and Notifications, 1970-89 at page, No. 726).

Conditions for the grant of extension of the bonding period.-.(1) Every bond delivered under the provisions of Section 92 of the Acl (Now Section 86) should be executed for full period of three years which goods may remain in a warehouse subject to the provisions of Section 103 of the Act. Extensions beyond this period will only be allowed in special cases with the previous approval of the Central Board of Revenue subject to the following conditions:--

(a) Good and sufficient cause to be required before an extension is granted.

(b) Any extension to be limited to the shortest period reasonably practicable.

(c) Application to be filed in time to permit of examination of the goods before expiry of the current period of the bond.

(d) A new bond to be executed for the duty still due.

(e) Duty to be calculated on the state of the goods as found at re-examination, provided that the regulation allowance for wastage be not executed.

(Boards letter D. Dis. No. 1034Cus/25, dated 13t/h October, 1925-S.O. $125 / 25)$.

(2) In recommending any extension of the period of a bond information regarding (1) original date of the bond and (2) the date on which the last extension granted expires, should be furnished to the Board. (Board's ktter C. No. 8-Cus. 11/33, dated 22nd February, 1933).

Note..-Any extension bond that covered the goods for more than one 
vesscl would violate the provision of Section 92 (Now Section 86) of the Sed Customs Act, and could not be enforced in a Court of Law. Hence, when extensions of the warehousing period are allowed, a separate bond should be taken for goods imported by each vessel. (Board's letter R.Dis. No.66-Cus. 11/28, dated 10th August, 1928-S.O.157 of 1928. Also see page 190 of the General Manual of Orders relating to Customs and Tariff Laws (Edition 1964).

99 Power to remove goods from one warehouse to another in the same customs station.--(1) Any owner of goods warehoused under this Act may, within the period of their warehousing under section 98 , and with the permission of the Collector of Customs, on such conditions and after giving such security, if any, as the Collector directs, remove goods from one warehouse to another warehouse in the same warehousing station.

(2) When any owner desires to remove any goods, he shall apply for permission to do so in such form as the Board may prescribe.

\section{NOTES}

Generul.-- This section corresponds to Section 104 of the Sca Customs Act. The provisions apply to removal of goods from one warehouse to another in the same customs-station whereas under the Sea Customs Act it was restricted to the same port.

Delegation of Collector's power to the Assistant Collector..-The Central Board of Revienue has impowered the Assistant Collector of the Oil Station Kmari Karachi to exercise the powers of the Collector of Customs as specificu in sub-section (1) of Section 99 of the Act subject to the condition that we satisfies himself that this does not involve any loss of Revenue. (See Notification No. S.R.O. 819(I)/\&\& dated 17th September, 1988, reported as PTCL 1989 St. 262 (ii) or page 771 of the Customs Rules and Notifications, 1970-89 by Najib A. Choudhry - An allied publicalion).

Rroforma of the application for the removal of bonded goods.--For Form (See Notification No. S.R.O. 812(I)/72, dated 30h/ September, 1972 , reproduced at page 111 of the Customs Rules and Notifications, 1970-89 by Najib $A$. Choudhry - An allied publication). 
slations whether al port or in the interior of the country.

\section{Goods on arrival at customs-station of destination to be} subject to same laws as goods on first importation.--Upon the arrival of warehoused goods at the customs-station of destination, they shall be entered and warehoused in like manner as goods are entered and warehoused on the first importation thereof, and under the laws and rules, in so far as such laws and rules are applicable, which regulate the entry and warehousing of such last mentioned goods.

\section{NOTES}

General.--This section is the verbatim reproduction of Section 108 of the Sea Customs Act, 1878.

\section{Clearance of bonded goods for home-consumption...} Any owner of warehoused goods may, at any time within the period of their warehousing under section 98 , clear such goods lor home-consumption by paying-.

(a) the duty assessed on such goods under the provisions of this Act; and

(b) all rent, penalties, '[surcharge] and other charges payable in respect of such goods.

\section{Legal Reference}

1. Substiluted for the word "interest" by the Finance ACl, 1985 with effect from 1st July, 1985.

\section{NOTES}

General...This section corresponds to Secticin 110 of the Sea Customs Act. The time within three years has been omitted from the section. thas provided the time within the period of their warehousing i.e. one year wich can be reduced or extended under Section 98 of the present Act. Further the payment of duty covers the duty assessed on such goods under the provisions of this Act. Under the old law it was the duty assessed on such pods under Section 87 of the Sea Customs Act or the duty altered under ertain provisions of the Sea Customs /.ct 
Duty on goods cleared after or without bonding them.--Duty in respect of goods cleared without bonding them is charged at the rate when Bill of Entry is made whereas in respect of bonded goods the duty is charged at ratc prevailing on the datc of actual remnoval of goods from warchouse

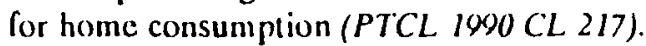

Rules for clearance of goods for Indus Basin Project... For Rules sec Notification No. S.R.O. 1208(K)/71, dated 25th October, 1971, reproduced at page 71 of the Cusioms Rules and Notifications, 1970-89 by Najib A. Choudhry - An allied publication.

\section{Clearance of warehoused goods for export.--Any owner} of warehoused goods may, at any time within the period of their warehousing under section 98, clear such goods for export out of Pakistan on payment of all rent, penalties, '[surcharge] and other charges payable as aforesaid but without paying any import duty thereon:

Provided that, if the ${ }^{2}[$ Federal Government] is of the opinion that warehoused goods of any specified description are likely to be smuggled back into Pakistan, it may, by Notification in the official Gazette, direct that such goods shall not be exported to any place outside Pakistan without payment of duty or allow them to be exported subject to such restrictions and conditions as may be specified in the Notification.

\section{Legal References}

1. Substituted for the word "interest" by the Iinance Act. 1985 with effect from 1st Jub. 1985.

2. Substiluted for the words "Central Covernment" by the Finance Ordinance, in with effect from $17 \mathrm{th}$ June, 1972.

\section{NOTES}

General.--This section corresponds to Suction 111 of the Sa Customs Act with the following changes:--

(i) the time within three years have been omilled. The period of three years can be reduced or exicnded under Section 98

(ii) the provisions have been made to protibit the export d 
such warchoused goods, without payment of duty, as are likely to be smuggled back into Pakistan or allow them to be exported without payment of duty subject 10 such restrictions and conditions as imposed by the Federal Government by Notification.

Rules for the clearance of goods from factory warehouse for manufacture of export goods..For Rules sec page 21 of Part 1--Customs Rules and Notifications, 1970.

\section{Clearance of warehoused goods for export as} provisions, on a conveyance proceeding to foreign destination.-.Any warehoused provisions and stores may be exported within the period of their warehousing under section 98 without payment of import duty for use on board any' conveyance proceeding to a foreign territory.

\section{NO'TES}

General...This section corresponds to Seclion 112 of the Sea Customs Act. The provisions have been extended to all conveyance including vesscls.

Stores shipped from bond on a vessel proceeding to a foreign port via one or more customs-ports... The Government have decided that free shipment from bond under Section 112 of the Sea Customs Act (corresponding to Section 106 of the present Act), should be allowed on stores shipped on a vessel procededing to a forcign port via one or more customs-ports provided the vessel is engaged in forcign I rade.

According to G.l.I. and C. Department's leller No. 3275, dated $28 \mathrm{th}$ September, 1881, to the Government of Bengal, a vessel should be regarded as engaged in foreign trade if it is going to another customs port to lake in cargo for a foreign port or when it is going to a forcign port but carries some cargo for a customs-port at which it is to louch en routc. No duty should be recovered on such stores if consumed in reasonable quantitics in Pakistan waters (Am. O. Gl. 5/46, printed at p. 198 of the General Manual of Orders relating to Customs and Tariff Laws, 1964).

Orfences and penalties.-Sc' clause (56) of Section 156(1) of the Act. 
107. Application for clearance of goods:--(1) An application to clear goods from any warehouse for home-consumption or for export shall be made in such form as the Board may prescribe.

(2) Such application shall ordinarily be made to the appropriate officer at least twenty-four hours before it is intended to clear such goods.

\section{NOTES}

General.--The present scction contains same provisions as existed in Scclion 113 of the Sca Customs Act.

Appropriate Oflicer...The Superintendent/Principal Appraiser of Customs has been assigned the functions of the "approprialte oflicer":--

to act under this section; and

to extend the time for submission of application for clcarance of warchoused goods.

(See Notification No. S.R.O. 806(l)/84, dated 20th Scptember, 1984, reponed as PTCL 1985 St. 25 or page 909 of the Customs Rules and Notifications, 1970-89 by Najib A. Choudhry - All allied publication).

Also see Notes under Section 224.

Form of applications..-Bill of Entry and Shipping Bill should be regarded as application under this section as the goods are entered for clearance from warehouse for home consumption or for exportation as merchandise or stores. (see page 199 of the General Mannal of Orders-. Edition 1964).

\section{Re-assessment of warehoused goods when damaged or} deteriorated.--If any goods upon which duties are levied ad valorem '[or otherwise] are damaged or deteriorated due to an unavoidable accident or cause after they have been entered for warehousing and assessed under section 80 and before they are cleared for home-consumption, their value in the damaged or deteriorated state may be appraised, '[according to either of the methods provided in sub-section (2) of section 27] if the owner so desires, by an officer of customs and the duty leviable 
thereon shall be diminished in proportion to the diminution of their value and a new bond for twice the amount of the diminished duty may, at the option of the owner, be executed by him to replace the bond originally executed.

\section{Legal References}

1. These words were inserted by the Finance Act, 1986 with effect from Ist Juty, 1986.

2. These words were inserted by the Finance Act, 1986 with effect from Ist July, 1986.

\section{NOTES}

General...This section corresponds to Section 114 of the Sea Customs Act. Provision has also been made for the re-assessment of deteriorated goods. This provision has been so modified as to secure that the reassessed duty will abate in the same ratio as the value of the damaged or deteriorated goods. This is an conformity with the principle contained in Section 27.

Unavoldable accident...The words "unavoidable accident" appearing in Section 114 of the Sea Customs Act, 1878 (corresponding to Section 108 of this Act), should not be considered to cover the case of goods which have deteriorated or become worthless owing to the elfects of ordinary climatic conditions, (S.O. 128 of 1925, reproduced at p. 199 of the General Manual of Orders relating to Customs and Tarif( Laws, 1964).

Goods subject to specilic duties.--This section applies only to goods upon which ad valorem dutics are payable. It does not apply to goods on which specific dutics are payable. In the case of any damage to such goods while they are warchoused, the owner may have them destroyed and oblain remission of duty under Section 94(2).

\section{Re-assessment on alteration of duty.--If any goods have} been entered for warehousing and assessed under section 80 but the duty leviable thereon is subsequently altered, such goods shall be re-assessed on the basis of the altered duty and a new bond shall be executed by the owner in accordance with the provisions of section 86 to replace the bond originally executed by him.

\section{NOTES}

General...This section corresponds to Section 115 of the Sea Customs Act. Provision has been made for exccution of fresh bond on the 
basis of altered duty to replace the original bond if that fell short to cover the altered duty.

\section{Allowance in case of volatile goods.-. When any} warehoused goods of such class or description as the Board having regard to the volatility of such goods and the manner of their storage may, by Notification in the official Gazette, specify are, at the time of delivery from a warehouse, found 10 be deficient in quantity and the Collector of Customs is satisfied that such deficiency is on account of natural loss, no duty shall be charged on such deficiency.

\section{NOTES}

General.-.This is virtually a new provisions which replaces Sections 116 and 117 in the following manners:--

The concession which was given under the Sea Customs Act in respect of wine, spiril and beer in casks and salt will now be admissible in respect of such volatile goods which the Federal Government may notify. The concession in respect of natural loss of wine, spirit and beer has been extended to other volatile goods.

(ii) The provisions laying down the maximum pereentage of deficiency and giving discresion to the Board to charge the limits generally and to the Collector of Customs to modify the limit in individual cases, have been omilted. Henceforth duty will be remitted by the Collector of Customs on the quantity genuinely found deficient due to natural loss, without fixing any statutory maximum limit.

Change of duty in excess of admissible wastage... In exercise of the powers conferred by Section 9 of the Sea Customs Act, 1878 (VIII of 1878) and in supersession of the Government of Bombay Notification No.3301, dated the 23rd May, 1888, the Central Board of Revenue is pleased to declare that at warehousing ports in Karachi and Chittagong liquors in wood which are removed from a bonded warehouse for shipment to a foreign port shall before shipment be gauged, and import duty shall be charged on any deficiency in excess of such allowance as would be made under Sections 116 and 117 of the Sea Customs Act, if such liquors were cleared for homeconsumption. 
111 Duty on goods improperly removed from wárehouse or allowed to remain beyond fixed time or lost or destroyed or taken as sample.--In respect of goods specified hereunder the appropriate officer may demand and upon such demand the owner of such goods shall forthwith pay the full amount of duty chargeable on such goods together with all rent, penalties, '[surcharge] and other charges payable in respect of them, namely:--

(a) Warehoused goods which are removed in contravention of section 97.

(b) Goods which have not been removed from the warehouse within the time allowed for such removal under section 98 .

(c) Goods in respect of which a bond has been executed under section 86 and which have not been cleared for home-consumption or export or removed in accordance with the provisions of this Act and are lost or destroyed otherwise than as provided in sections 94 and 95 or as mentioned in section 115 , or are not accounted for to the satisfaction of the appropriate officer.

(d) Goods which have been taken under section 94 as samples without payment of duty.

\section{Legal Reference}

Substituted for the word "interest" by the Finance $A c 1.1985$ with effect from ist July, 1985.

\section{NOTES}

General.--This section corresponds to Section 118 of the Sea Customs Act. Substantially it is the same provision though mode of expression has been chanecd.

Appropriate Omicer.-The Assistant Collector of Customs has been essigned the function of the "appropriate officer" to act under this section. (See Notification No. S.R.O. $806(l) / 84$, dated 20th September, 1984 repored as PTCL 1985 St. 25 or page 909 of the Custons Rules and Notifications, 1970 
[Secs. 111-113]

89 by Najib A. Choudhry - An allicd publication).

Duty and penalty on goods in properly renoved.--Duty and Penally on the goods improperly removed from warehoue can be levied and imposed under Section 111. Simply mention of wrong section in the order does not invalidate it (PTCL 1990 CL 217).

Application of time limits of Section 32.-.Provisions of sub-section 32(2) and (3) regarding limitation are also applicable to charge leviable under Section 111 read with Section 98 (PTCL 1989 CL 60).

\section{Procedure on failure to pay duty, etc.--(1) If any owner} fails to pay any sum demanded under section 111, the appropriate officer may either proceed upon the bond executed under section 86; or cause such portion of the owner's goods in the warehouse to be detained as he may consider adequate to recover the demand, and a notice in writing of such detention shall immediately be given to the owner.

(2) In case the demand is not discharged within fifteen days of the date of such notice, the goods so detained may be sold.

(3) The net proceeds of any such sale shall be entered upon and adjusted against the bond and the surplus if any remaining after full satisfaction of the bonds shall be disposed of in the manner provided in section 201.

(4) No transfer or assignment of the goods shall prevent the appropriate officer from proceeding against such goods in the manner above provided, for any amount due thereon.

\section{NOTES}

General.--This section corresponds to Section 119 of the Sea Customs Act with the following changes:--

(i) It permits the appropriate officer to detain and sell any warehoused goods belonging to the person concerned instead of only the gonds on account of which any duty is due. 
(ii) The period to discharge the demand on notice has been extended to fifteen days from ten days.

(iii) The period of one ycar for making application for refund of the surplus sale proceeds has been reduced to six months. Now the application is to be made within six months of the sale of the goods and thereafter on showing sufficient cause for not doing so.

Appropriate Ollicer..-The Assistant Collector of Customs has been assigned the function of the "appropriatc officer"--

(i) to act under this section; and

(ii) to extend the time for payment of duty under sub-section (2).

(See Notification No. S.R.O. $806(I) / 84$, duted 201h Septomber, 1984 reported as PTCL 1985 St. 25 or page 909 of the Customs Rules and Notifications, 1970-89 by Najib A. Choudhry - An allied publication).

Also See "Notcs" under Section 224.

Procedure for sale of goods and application of sale proceeds...Sec Scclion 201 of the Act.

Expenses of carriage, packing, etc., to be borne by owner.--Sce: Scetion 119 of the Act.

Meaning of words "detain" and "detention"...The expression "detention" or "detain" cannot be construcd as "seizure". These words have not been defined in the Act and as such dictionary meanings would be taken in construing the provisions of this section (PTCL 1986 CL. 253). Now the words "detain" and "seizurc" have been defined in the Act. For definition see cliuses (kk) and (rr) of Section 2 of the Customs Act, 1969.

\section{Noting removal of goods.-(1) When any warehoused} goods are taken out of any warehouse, the appropriate officer shall cause the fact to be noted on the back of the bond.

(2) Every note so made shall specify the quantity and description of such goods, the purposes for which they have been removed, the date of removal, the name of the person removing them, the number and date of the bill of export under which they have been taken away, if removed for 


\section{5}

exportation, or of the bill of entry, if removed for homeconsumption and the amount of duty paid, if any.

\section{NOTES}

General.--This section corresponds to Section 120 of the Sea Customs Act. Substantially there is no change.

Appropriate Oficer.--The Central Board of Revenue has assigned the functions of the "appropriate officer" under this section to Inspector/ Preventive Officer/Examiner of Customs. (See Notification No. S.R.). 806(I)/84, dated 201h September, 1984, reponed as PTCL 1985 St. 25 or page 909 of the Customs Rules and Notifications, 1970-89 by Najib A. Choudhry . An allied publication).

Particulars to be noted.--This section requires that when any goods are removed from a warehouse, the appropriate officer shall note on the back of the warehousing bond entered into by the owner of the goods under Section 86--

(1) the quantity and description of the goods removed;

(2) the purposes for which they have been removed;

(3) the date of removal;

(4) the name of the person removing them;

(5) if the goods have been removed for exportation, the number and date of the export bill under which they have been laken away;

(6) if the goods have been removed for home-consumption, the number and date of the bill of entry; and

(7) the amount of duty paid (if any).

The appropriate officer is also required to enter the above particulars in the register of bonds kept under Section 114. Section 114.

Register of bonds and cancellation and return of bonds.--See

114 Register of bonds.--(1) A register shall be kept of all bonds entered into for customs-duties on warehoused goods, and entry shall be made in such register of all particulars required by section 113 to be specified. 
(2) When such register shows that the whole of the goods covered by any bond have been cleared for homeconsumption or export, or otherwise duly accounted for, and when-all amounts due on account of such goods have been paid, the appropriate officer shall cancel such bond as discharged in full, and shall on demand deliver the cancelled bond to the person who executed it or who is entitled to receive it.

\section{NO'TES}

Generul.--This section corresponds to Section 121 of the Sea Customs Act. There is no change.

Appropriate Olticer.--The Central Board of Revenue has assigned the functions of the "appropriate officer" under. this section to Superintendent/Principal Appraiser of Customs. (See Notificution No. S.R.O. 806(I)/84, dalced 20th Scptember, 1984, reponced as PTCL 1985 St. 25 or page 909 of the Customs Rules and Notifications, 1970-89 by Najib A. Choudhy : All allied publication).

115 Power to renit duties on warehoused goods lost or destroyed.-.-If any warehoused goods in respect of which a bond has been executed under section 86 and which have not been cleared for home-consumption are lost or destroyed by unavoidable accident or cause, the Collector of Customs may in his discretion remit the duties due thereon:

Provided that, if any such goods be so lost or destroyed in a $\left.{ }^{1}{ }^{*} * *\right]$ warehouse, notice thereof be given to the appropriate officer within forty-eight hours after the discovery of such loss or destruction.

\section{Legal Reference}

1. The word "private" onitted by the Finance Act, $1 \%(0$ with elfect from lst July, $1 \%(x)$.

\section{NOTES}

General.--This section substantially cmbodies the provisions of Section 122 of the Sea Customs Act.

Appropriate Otticer.--The Assistant Collector of Customs has been 
assigned the functions of the "appropriate officer" to act under this section. (See Notification No. S:R.O. 806(I)/84, dated 201h September, 1984, reponed as PTCL 1985 St. 25 or page 909 of the Custons Rules and Notificutions, 1970$\delta 9$ by Najib $A$. Choudhry - An allied publication).

Unavoidable accident.--Black's Law Dictionary defincs the expression thus:

"An incvitable accident; one which could not have been fore-seen and prevented by using ordinary diligence, and resulting without fault. Not necessarily an accident which it was physically impossible, in the nature of things, for the person to have prevented, but one not occasioned in any degrec, cither remotely or directly, by the want of such care or skill as the law holds every man bound to exercise. An accident which could not he prevented by the exercise of ordinary care and prudence. A casualty which occurs wilhout negligente of either party and when all means which common prudence suggests have been used to prevent it".

Unavoidable cause.-.In Black's Law Dictionary the expression has been defined thus:

"A cause which reasonably prudent and careful men under like circumstances do not and would not ordinarily anticipatc, and whose effects, under similar circumstances, they do not and would not ordinarily avoid".

Lord Alverstone C.J., while considering the question whether a child had been prevented from attending school by any "unavoidable cause" for the purposes of the bye-laws made under the Elementary Education $\mathrm{Act}, 1870$, observed:

"If a parent sends a child in such a condition that the child will be refused admission, the fact that the child is refused admission does not amount to the child's being prevented from altending school by an unavoidable causc." (Walker vs. Cimmings (1912) 107 L.T. 304, 305).

\section{Responsibility of warehouse-keeper.--The warehouse-} keeper in respect of goods lodged in a public warehouse, and the licensee in respect of goods lodged in a private warehouse, shall be responsible for their due receipt therein and delivery therefrom, and their safe custody while deposited thereill, according to the quantity, weight or gauge reported by the 
,

[Cb. XI]

Warchousing

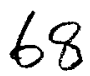

officer of customs who has assessed such goods, allowance being made, if necessary, for deficiency in quantity on account of natural loss as provided in Section 110:

Provided that no owner of goods shall be entitled to claim from the appropriate officer or from any keeper of a public warehouse, compensation for any loss or damage occurring to such goods while they are being passed into or out of such warehouse, or while they remain therein, unless it be proved that such loss or damage was occasioned by the wilful act or neglect of the warehouse keeper or of an officer of customs.

\section{NOTES}

General.--This seclion corresponds to Section 123 of the Sea Customs Act. A proviso has been added which protects the warehouseleeper and appropriate officer against the compensation for any loss or damage occurring to the goods while they are being passed into or out of the warchouse, or while they remain therein unless it be proved that the loss or damage was occasioned by wilful act or neglect of the warchouse-keeper or of an officer of Customs.

This section defines the liability of the owner of the warchouse in respect of the goods deposited in the warchouse (51) I.L.R. (1951) I Cal. $(\$ 4\})$.

Appropriate Oflicer.--The Collector of Customs has been assigned the functions of the "appropriate officer" to act under this section. (Sec Nolification No. S.R.O. SO6(I)/84, dalcd 20th September, 1954, reported as PTCL 1985 St. 25 or page 909 of the Customs Rules and Norificarions. 1970-89 by Najib A. Choudhry - All allicd publication).

Goods lost from K.P.T. Warehouses.-.The Customs Dipartment in their leller, N.O.C. 445, daled 18th February, 1932, have laken the following new in regard 10 goods lost from such warehouses:--

"Under the provisions of Section 123, Sea Customs Acl, (now Section 116 of the Customs $\mathrm{ACl}$ ) the Karachi Port Trust as employers of the warehouse-kecper, are responsible for the duty on goods warehoused in their public warehouses and lost from their custody. Goods deposited in the so-called private compartments cannot be treated differently from those in other portions of the Port Trust licensed warehouses. The Karachi Port Trust are the licensees of the 


\section{9}

[Secs. 116-119]

warchouses, they receive the rent therelrom and must be held responsible for the securily of such warehouses". (General Manual of Orders, 1964, p. 205).

Orfences and penalties.--See clauses (57) and (58) of Section 156(1).

117 Locking of warehouses.--(1) Every public warehouse shall be under the lock and key of both the warehouse-keeper appointed by the Collector of Customs, and the appropriate officer.

(2) Every private warehouse shall be under the lock and key of both the licensee and the appropriate officer.

\section{NOTES}

General.--This section corresponds to Section 124 of the Sea Customs Act. Provision has been made for the joint custody of private warchouse i.e., of the licensec and the appropriate officer of the Customs Department.

Appropriate Oflicer.--The Central Board of Revenue has' assigned the functions of the "appropriale officer" under this section to Inspector/Preventive Officer/Examiner of Customs. (See Notification No. S.R.P. $806(I) / 84$, dated 20k September, 1984, reported as PTCL 1985 St. 25 or page 909 of the Customs Rules and Notifications, 1970-89 by Najib $A$. Choudhy - An allied publication).

\section{Power to decide where goods may be deposited in public} warehouse, and on what terms.--The Collector of Customs may from time to time determine in what division of any public warehouse '[or a private warehouse], and in what manner, and on what terms, any goods may be deposited, and what sort of goods may be deposited in any such warehouse.

\section{Legal Reference}

1. These words were inserted by the Finance Ordinance, 1984 with effect from 14th June, 1984.

\section{NOTES}

General.--This section reproduces the provisions of Section 125 of 
the Şca Customs Act, 1878.

119 Expenses of carriage, packing, etc., to be borne by owner.--The expenses of carriage, packing and storage of goods on their receipt into or removal from a public warehouse shall, if paid by the appropriate officer or by the warehouse-keeper, be chargeable on the goods and be defrayed by, and recoverable from, the owner, in the manner provided in section 112.

\section{NOTES}

Generul.--This section is the same as Section 126 of the Sea Customs Act, 1878.

Appropriate Oflicer.--The Inspector/Preventive Officer/Examiner ate assigned the functions of the appropriate officers under this section. (sec Nolification No. S.R.O. $806(1) / 84$, dated $20 t h$ September, 1984, reponted as PTCL 1985 St. 25. or page 9(0) of the Customs Rulcs and Notifications, 197069 by Nujib $A$. Choudhry - An allicd publication).

Procedure on fallure to pay expenses.-. For procedure see Section 112 of the Customs Act, which is applicable for recovery of the expenses under this section. 


\section{CHAPTER XII \\ 71}

\section{TRANSHIPMENT}

provisions of this Chapter shall not apply to goods imported by post.]

\section{Legal Reference}

1. Section 120 sulsstituted by the linance Ordinance, 1979) with effect from Junc, $197 \%$. Prior to substitution Section 120 was as under:--

"120. Chapter not to apply to haguage or postal articles... The provision of this Chapter shall not apply to (a) haggage or (b) goxds imported by post."

\section{NOTES}

General.--This section is new. It provides that the provisions of Chapter XII which is about transhipment will not apply to articles and goods imported by Post, for the transhipment of which, separate provisions are contained in Chapter XV.

Transhipment--meanings.--Transhipment is the taking of the cargo out of one vessel and loading it in another vessel. The word is also used to denote the pracing of goods from one railway line 10 another line or from one railway system to another system for the purpose of carrying them from the place of consignment to the place of destination. In Black's Law. Dictionary, "transhipment" has been defined as: "In maritine law the act of taking the cargo out of one ship and loading it on another." In the Customs Act, 1969), "ranshipment" is used in the sense of removal of imported goods at a customs-station from one conveyance (vesscl, aircraft, vehicle or animal) to another for being taken 10 annther customs-station or a forcign destination.

\section{Transhipment of goods without payment of duty.--} Subject to the provisions of section 15 and the rules, the appropriate officer may, on application by the owner of any goods imported at any customs-station and specially and distinctly. manifested at the time of importation as for Iranshipment to some other customs-station or foreign gdestination, grant leave to tranship the same without payment of duty, if any, chargeable on such goods at the customs-station of transhipment and, in the case of goods to be transhipped to 
4. Explosives, as defined in the Explosives Act, '1884 (IV of 1884).

5. Arms and ammunition and parts thereol, as defined in the ${ }^{2}$ [Arms Acl, 1878 (XI of 1878)].

(For Notification see PTCL 1983 St. 352)

Transhipment permit.--A transhipment permit issued under Section 128 of the Sea Customs Act, 1878, does not, like a bill of lading represent the guods mentioned in it, or give any lien or control over then (1. LRC Bom. 477).

Rules regarding the transhipment of goods other than postal articles at the port of Karachi.-.See Notification S.R.O. No. 698(I)/73, dated 17th May, 1973. (Reproduced at page 127 of the Customs Rules and Notifications, 197(1)-89 by Najib A. Choudhry - An allic(d publication).

The Customs Transhipment of Goods to Customs Port Rules, 1973.--Sce Notification No. S.R.O. 1332(I)/73, dated 17th September, 1973. (Reproduced at page 1.30 of the Cusstoms Rules and Notifications, 1970-89 by' Najib A. Choudhn' - An allicd publication).

Omences and peralties.--Sec clause (63) of Section 156(1) of the Act.

Prohibited goods.--Se Section 15 of the Act.

122 Superintendence of transhipment..-An officer of customs shall, in every case, be deputed free of charge to superintend the removal of transhipped goods from one conveyance to another.

\section{NOTES}

General.--This section embodies the provisions of Section 129 of the Sea Customs Act. II has been extended so as to apply to all conveyances.

Goods lying on wharf under Customs supervision.--In the case of pouds lying on the wharf or in cargo boats pending transhipment, unless the pords are secured in closed sheds on the wharl, a special customs peon whuld be posted for supervision at the expecinse of the parly concerned till the poods are actually transhipped on board the on-carrying vessel. (S.O. 58 of

The Arms Act. 1878. has been repealed in its applicalion to the areas comprised in the former Province of West labistan except the provisions relating to manufacture (including conversion). export or import of arms, ammunitions and military stores by the West Pakistan Arms Ordinance. 1965 (W.P. (Ord XX' of I'65). 
1933, see page 208 of the Ciencral Manmal of Orders relating to (itstoms and Tariff Laws, 1964).

123 Entry, etc., of transhipped goods.--All goods trinshipped under section 121 to any customs-station shall, on their arrival at such customs-station, be entered in the same manner as goods on their first importation and shall be dealt with likewise.

\section{NO'TES}

General.--This section too exactly embodics the provisions of Scetiun 131 of the Sea Customs Act. These provisions are applicable at all customs. stations.

Date for determination of value and rate of duty in case goods un transhipped to another place.-.Siec Noles under Sections 30, 31 and 31-A.

Trunshipment pernit.--A transhipment permil issued under Scclion 128 of the Sea Customs Act, 1878, does not, like a bill of lacling represent the goods mentioned in it, or give any lien or control over them (I. LRC Bom. 477). (PTCL 1989 CL. 312).

Relevant date for deternining the value of and rate of duty applicable to transhipped goods.--Certain goods which were to be transhipped to Dry Port Lahore arrived at Karachi cusloms-port and wose manifested prior to 5th June, 1976. The bills of entry in respect of these goods were presented before their arrival at Karachi. The goods on arrival at Karachi were transhipped to Lahore where they arrived after 5th June, 1979 when by the Finance Act, 1976, the import duty on the said goods was raised by $10 \%$. The customs authorities accordingly demanded duty on the said goods at the enhanced rate which demand was resisted by the owner of the goods who filed a Constitutional petition in the Lahore High Court to contest the claim. A learned Single Judge allowed the petition on the ground that a the bills of entry in respect of the goods had been presented before 5th June 1976, and their importation was completed before the said datc, they were not liable to duty at the enhanced rate. It was observed that Sections 121-12 in Chapter XII of the Customs Act, 1969, which pertain to transhipment, "ordinarily have no relevance to the datc of detcrmination of value or rated duty", that the said date is to be determined by the date of presentation of the bill of entry and that the "entry of the goods at the second place may bx meant only to verify the goods as far as their quantily is concerned but theis importation is already comiplele". (PLD 1980 Lah. 469). 


\section{Transhipment of provisions and stores from one} conveyance to another of the same owner without payment of duty,--Any provisions and stores in use or being carried for use on board a conveyance may, at the discretion of the appropriate officer be transhipped to another conveyance belonging wholly or partly to the same owner and present simultaneously at the same customs-station, without payment of duty.

\section{NOTES}

General...This section corresponds to Section 132 of the Sea Customs Act. Its provisions have been extended so as to apply to all conveyances.

"Appropriate Ollicer"..-The Superintendent/Principal Appraiser of Customs have been assigned the functions of the "appropriate officer" to act under this section (Sec Notification No. S.R.O. $806(I) / 84$, dated 20th Sepiember, 1984, reponced as PTCL 1985 St. 25 or page 9(K) of the Customs Rulles and Notifications, 1970)- $\$ 9$ by Najib A. Choudhry - An allied publicution).

125 Levy of transhipment fees.-.Subject to the rules, a ranshipment fee on any goods or class of goods transhipped under this Act may be levied at such rates, according to weight, measurement, quantity, number, bale, package or container, as the Board may, by Notification in the official Gazette, prescribe for any customs-station or class of customs-stations.

\section{NO'TES}

General..-This section corresponds to Section 133 of the Sea Customs Act. The powers of the Board to make rules for transhipment and rubitition and regulation restriction of transhipment of goods without Ayment of duty; powers of officers of Customs in that behalf; and the lees tx transhipment, are contained in rule 219 read with item (12) of the Third khedulc to the Act.

Rates for transhipment fees.--The Central Board of Revenue under Wification No. S.R.O. 116(I)/83, dated 12th February, 1983 has prescribed kefollowing rates of transhipment fees to be levied for ceach transhipment to 
any goods at any Customs port, namcly:--

Rs. 2.00 per package/balc.

With a minimum of Rs. $20.0 \%$ and maximum of Rs. 1,000.00 per consignment:

Provided that in calculating the fee in the case of wrought iron, such as bars, rods, plates, sheets, hoop, old pig, pipes and lubes and lin plates; of other loose metal and of oil; timber; salt and other articles in bulk, each metric ton or portion of a metric $l o n$ shall he laken as representing one package:

Provided further that no transhipment fee shall be chatged for the transhipment of goods from a customs port to an inland customs-station or warehousing station. (For Notification No. S.R.O. 116(l)/8.3, sec PTCL 1983) St. 33.5(i) or page 400 of the Customs Rules and Notifications, 1970-80 by Najib A. Choudliny - An allicd publication). 


\section{CHAPTER XIII \\ 76 TRANSIT TRADE}

126 Chapter not to apply to baggage and postal articles..The provisions of this Chapter shall not apply to (a) baggage, and (b) goods imported by post.

\section{NOTES}

General...This section is new. It mentions specifically that the provisions of Chapter XIII shall not apply to baggage and goods imported by post, for which separale provisions have been made in Chapter XV.

Transit...Goods are deemed to be in course of transit from the time when they are delivered to a carrier by land or water, or other bailee for the purpose of transmission to the buyer, until the buyer, or his agent in that tehall, takes delivery of them from such carrier or other bailee. (3t Halsbury's Laws of England (3rd Edn.) 128).

The Customs Act, 1969, however deals with transil of goods (including provisions and stores) from one customs-station in Pakistan 10 another customs-station or 10 a destination outside Pakistan, either in the same conveyance or in another conveyance.

\section{Transit of goods in the same conveyance.--(1) Subject} to the provisions of section 15 and the rules any goods imported in a conveyance arid mentioned in the import manifest as for transit in the same conveyance to a customsstation in Pakistan or to any destination outside Pakistan may be allowed to be so transitted without payment of duty, if any, leviable on such goods at the customs-station of transit.

(2) Any stores and provisions imported on board a conveyance which is in transit through Pakistan to a destination outside Pakistan may, subject to rules, be allowed to be consumed on board that conveyance without payment of the duties which would otherwise be chargeable on them.

\section{NOTES}

General..--It is a new provision which provides that goods mentioned 
in an import manifest as for transil in the sance conveyance to customs. station in Pakistan or to any destination outside Pakistan may be allowed to be so transitted without payment of duty. The section also makes it clear that the prohibitions on the bringing or taking of goods, as specified in Section is or any rule, into or out of Pakistan, shall apply to such goods. Such prohibitions may, however, be relaxed in suitable cases by the Federal Government by an order under Section 15 of the Act itself.

Sub-section (2) provides for the consumption of any stores and provisions by conveyances otherwise chargeable to duty, free of duty subject to rules made for that purpose.

Exemption from the provision of Section 15 of the Act--All goods in transit through Pakistan to any destination outside Pakistan under this section have been excmpted from the provisions of Section 15 of the Act. (Notification No. S.R.O. I(I)/70, dated lst January, 1970). For Notification see page 3 of the Customs Rules and Notifications, 1970-89 by Najib A. Choudhy. An allied publication).

Rules for regulating consumption of stores and provisions on board a conveyance which is in transit through Pakistan to a destinativo outside Pakistan.--See Notification No. S.R.O. 425(I)/73, dalced 24th March, 1973. (Reproduced at page 119 of the Customs Rules and Notifications, 1970. 89 by Najib A. Choudhry - An allied publication).

\section{Transport of certain classes of goods subject 10} prescribed conditions.--Any goods may be transported from one part of Pakistan to another through any foreign territory, subject to such conditions as to their due arrival at the destination as may be prescribed by rules.

\section{NOTES}

General.--It is also a new provision which provides transport of goods from one part of Pakistan to another through any foreign territury. Due arrival of goods at the destination will be ensured by making necessary provisions in the rules.

nanis.--No rules under this section appear to have been framed India, however, has framed the Transportation of Goods (Through Foreiga Territory) Regulations, 1969.

Orrences and penalties.--Sce clause (64) of Section 156(1) of the Ad 
129 Transit of goods across Pakistan to a foreign territory.-Where any goods are entered for transit across Pakistan to a destination outside Pakistan, the appropriate officer may, subject to the provisions of the rules, allow the goods to be so transitted without payment of the duties which would otherwise be chargeable on such goods.

\section{NOTES}

Generul.--lt is a new provision which provides that goods may be transitted across Pakistan to a forcign territory with the permission of the ippropriate officer subject to such conditions and restrictions as may be provided in the rules.

Appropriate Omicer.--The Superintendent/Principal Appraiser has teen assigned the functions of the appropriate officer for the purpose of provisions of Section 129 of the Customs Acl, 1969. (Sce Notification No. S.R.0. 806(I)/84, dated 20kh September, 1984, reported as PTCL 1985 St. 25 or poge 909 of the Customs Rules and Notifications, 1970-89 by Najib $A$. Ooudhry - An allied publication).

Phrase "subject to the provisions of the Rules".--meanings of.--The words "Subject to the provisions of the Rules" used in Section 129 of the customs Act, 1969 mean that appropriate officer is to give permission in kcordance with the provisions of the rule if any, and that if the rules are went as to the giving of permission that would not mean that no permission rould be required (PTCL 1986 CL 147).

Pernission of appropriate oflicer is necessary.--Even in the absence dany specific provision regarding permission in the rules, the permission of ppropriate officer is necessary. (PTCL 1986 CL 146).

Rules.-.-Although . . artion itself, the notes on the clauses and the xnally clause (section $15 \%$ (1), chatise (it), all make reference to rules for zuduating transit trade, no rules under this section have so far been framed. however, Afghan transit trade is being carried on and is governed by the zons of the Afghan Transit Trade Agreement, 1965, which agreement is aproduced hereinafter:--

THE AFGHAN TRANSIT TRADE AGREEMENT, 1965

[Kabul, the 2nd March, 1965]

AGREEMENT

IETWEEN THE GOVERNMENT OF THE ISLAMIC REPUBLIC OF PAKISTAN AND THE GOVERNMENT OF THE KINGDOM OF 


\section{AFGHANISTAN FOR REGULATION OF TRAFFIC IN TRANSIT}

The Governiment of the Islanic Republic of Pakistan and the Government of the Kingdon of Afghanistan being desirous of strenglhening the cconomic ties between their two countries on a mulually advantagious basis, improving the difficulties in the movement of goods through the Iwo countries, and having taken into consideration the present volume and fulure development of transit trade, have decided to conclude an agreement and to this and have appointed their plenipotentiarics as under:--

The Government of the Islamic Republic of Pakistan, Wahiduzzaman, Minister for Commerce

The Government of the Kingdom of Alghanistan, Mohamnad Sarwar Omar, Minister for Commerce

who have exchanged their full powers, found in good and due form, have agreed to the following articles:--

\section{Article-I}

The Contracling Parlies undertake in accordance with the provisions of this Agreement to grant and guarantee to each other the freedom of transit to and from their territories.

No distinction shall be made which is based on the llag of vessers the place of origin, departure, entry, exit or destination or any other, circunstances relating to the ownership of goods, of vessels or of othen means of transport.

Article-II

Goods including baggage, and vessels and other mcans of transpont shall be deemed to be in transit across the territory of a Contracting Panth when the passage across such lerritory with or wiltusul Iranshipmem, warehousing, breaking bulk or change in the mode of transport, is only portion of a complete journey beginning and terminating beyond the froniet of the Contracting Party across whose territory the traffic passes--Traffic of this nature is termed in this Agreemenl 'Traffic in Transil'.

Article-III

The transit routes shall be:

(1) Peshawar--Torkham and vice versa.

(2) Chaman--Spin Baldak and vice versa.

Additional routes may be agreed between the Contracling Parlid 
frim tine to lime. Goods moving via these routes shall be entered at the proper Customs post prescribed by each Party. Adequate transit and other facilities shall be provided by the Contracting Party concerned at these posts.

Article--IV

No Customs duties, taxes, dues, or charges of any kind whether national, provincial or municipal regardless of their name and purposes, shall be levied on traffic in transit except charges for transportation or those commensurate with the administrative expenses entailed by traffic in transit or with the cost of services rendered.

With a vicw to achicving simplification of existing Customis Practices and Procedures, the Contracting Partics agrec to adopt at points of entry and exit the procedures laid down in the Annex to this Agreement.

Article.-V

Without prejudice to the gernerality of the provisions contained in Article III, the Government of the Islamic Republic of Pakistan sha!l earmark sheds and open spaces in the Karachi Port Arca, to be known as Afghan Transit Arca, for the goods in Iransit 10 and from Afghanistan. For Hazardous and awkward goods scparate arrangeinents for storage will be made as indicated in the Annex.

Article.-VI

The two Contracting Partics, recognising the importance of the 'Kabul-Torkham-Peshawar transit routc, have decided to cxamine all mallers pertinent to the development of this routc, including further consideration of the extension of the railway from Landi Khana to Torkliam.

Article--VII

The Government of the Islamic Republic of Pakistan undertake to meet in full, the requirement of wagons for transit trallic on both KarachiSpin Baldak and Peshawar-Karachi roules.

Article.-VIII

Each Contracting Party shall appoint Liaison Officers to look into the working of this Agrcement, and to refer, for expeditious solution, to the appropriate authorities of their own country and to the Liaison Officer of the other country, any question arising from the operation of this Agreement. The Liaison Officers will nece as often as necessary and in any casc not less than once in six months and the contracting Parlics shall provide them with the necessary facilities. 


\section{Article--IX}

The Contracting Partics agrec that railway freight, port and other ducs shall be subject to the most sympathetic consideration and shall be no less favourable than those imposed by either Parly on goods owned by its own nationals.

\section{Article--X}

Nothing in this Agreement shall be construed to prevent the adoption and enforcement by either Party of measures necessary to protect public morals, human, animal or plant life or health and for the security of its own territory.

\section{Article XI}

The Contracting Parties shall meet and consult each other once a . year to review the working of this Agrcement.

\section{Articie--XII}

The Contracting Parties agree to resolve any difference relating to the interpretation of this Agreement by negotiation, and in the event of failure to reach a settlement, to refer the matter to an arbitrator acceptable to both Parties, whose decision shall be binding.

\section{Article.-XIII}

Nothing in this agreement or its Annexes will affect in any way the political stand of the two countries or the political difference existing betwcen them, and the contracting Partics fully reserve their rights with regard to these subjects.

\section{Article --XIV}

This Agreement shall be ratificd and the Instruments of Ratification shall be exchanged at Rawalpindi. The Agreement shall come into force from the date of the exchange of the Instruments of Ratification and shall remain in force for five years from the date it comcs into force. Unless notice of termination is given in writing by either Contracting Party to the other six months before the expiration of the five years period, thi Agreement shall be automatically renewed for a further period of live years. It can thereafter be terminated by either Party at any time provided six months notice of termination is given by cither party.

\section{Article..XXV}

The present Agrecment is drawn in duplicale in English and Dari Languages, both texts being equally valid. 
IN WITNESS THEREFORE, the undersigned, being duly authorised by their respective Governments, have signed, the present Agrecment.

Done in duplicatc in English and Dari at Kabul on 2nd March, 1965. For the Government of the Islamic Republic of Pakistan.

For the Government of the Kingdom of Afghanistan.

$\mathrm{Sd} / \cdot$

WAHIDUZZAMAN, MINISTER FOR COMMERCE.
$\mathrm{Sd} /-$

MOHAMMAD SARWAR OMAR, MINISTER FOR COMMERCE.

\section{PROTOCOL ANNEXED TO TRANSIT AGREEMENT SIGNED \\ BETWEEN THE GOVERNMENT OF THE ISLAMIC REPUBLIC OF PAKISTAN AND THE GOVERN- MENT OF THE KINGDOM OF AFGHANISTAN \\ DATED MARCH 2, 1965}

In accordance with the provisions of the Agreement signed in Kabul between the authorised representalives of the Contracting Parties on March 2, 1965, regulating Traffic in Transit to and from Afghanistan, the signatories, in order to regulate the transport of goods by lorrics from Peshawar to Kabul, and from Chaman to Kandahar and vice versa until such time as extension of rail and road is completed, have agreed as follows:

Article--1

The two Governments agree that there shall be open compctition for all trancmorlers for carriage of all category of goods to and from Afghanistan irrespective of ownership of goods.

Article.-2

The two Governments agrce to accord to transporters and clearing and forwarding agents from cither country national treatment.

Article -3

Determination of frcight rates shall be left to market conditions for gonds of all descriptions and denominations. No discrimination shall be made by the authoritics of either Government in the matter of allocation of freight ubetween the transporters of either country.

Article-4

Each Government agrees that no taxes shall be levied by it on 
transport velicles registered in the territory of the other country execpt by prior consultation and on basis of equality.

Article - -5

The two Governments agree that

(a) Route permits shall be issued by the country in which the vehicles are registered;

(b) Driving Licences and certilicates of liness in respect of transport vehicles covered by this Protocol issued in one country shall be valid in the other country also. Vehicles carrying petrolecion and petroleun prodacts shall continuc to be governed by existing practice regarding certilicales of litness; and

(c) The period for which vehicles of one country may stay in the other on each trip shall be fixed on uniform reciprocal basis.

\section{Article-6}

The two Governments agree to grant to transporters multiple entry visas valid for a period of six months at a time.

Article -.7

The two Governments agrec to grant to transport vehicles road permits valid for a period of six months at a lime.

Article. .8

The two Governments shall consult each other with a view to adopting necessary measures to facilitate the flow of traffic between the two countrics and shall seck all possible means within their power to remove any factors which may damage the normal accomplishment of the operation foreseèn in this Protocol.

Article--9

This Protocol shall come into force simultancously with the Agreement on Traflic in Transit signed on 2nd March, 1965.

Done in duplicate in English and Dari both, texts being equally authentic, in Kabul on the 2nd March, 1965.

Signed on behalf of the Government of the Islamic Republic of Pakistan.

WAHIDUZZAMAN, MINISTER FOR COMMERCE.
Signed on behalf of the Government of the Kingdom of Afghanistan.

MOHAMMAD SARWAR OMAR, MINISTER FOR COMMERCE. 
ANNEX ON THE CUSTOMS AND OTHER PROCEDURES TO THE AGREEMENT SIGNED ()N THE 2ND MARCH, 196,5 BETWEEN

THE GOVERNMENT OF THE ISLAMIC REPUBLIC OF

PAKISTAN AND THE ROYAL AFGHAN GOVERNMENT FOR REGULATING TRAFFIC IN TRANSIT

I. CUSTOMS AND OTHER PROCEDURES IN RESPECT OF GOODS AND PASSENGER'S UNACCOMPANIED BAGGGAGE ENTERING PAKISTAN FOR TRANSIT TO AF( IHANISTAN.

1. On arrival of the goods the owner or his agent shall at the lime of entering them at the Custom House.

(a) Declare that the goods are intended for such transit;

(b) Furnish in quadruplicate an invoice of the goods so declared in the prescribed form specifying therein by which of the two authorised routes the goods are intended to be transported viz.

(ii) Chaman--Spin Baldak.

(c) On compliance wilh the above provisions the documents will be completed on the basis of exemption from duty, Sales-tax and import trade control regulations after such inspection as may be considered necessary.

2. The further procedure in respect of goods arriving through Karachi will be as follows:--

The goods will be sealed, with Customs seal and removed from the Karachi Port Trust transit sheds; under Customs supervision, to the Afghan transit sheds specially set apary for the purpose under Customs physical control. Heavy goods such as machinery and iron or steel, etc. will be removed from the Karachi Port Trust transit areas under customs supervision and stored in enclosed open spaces, specially provided zir the purpose, under Customs control. Explosives and hazardous goods and heavy cargo exceeding 5 tons in weight for which special storage arrangements have becn provided by the Karachi Port Trust will not be removed to the transit shed or open space set apart for Afghan Transit goods.

3. The goods will be loaded under Customs supervision into railway wagons, exclusively provided for transit goods, which will be sealed by the Railway. In the case of open walgons loading heavy articles such as cars, trucks, machinery, iron and stecl, ele., sealing may be dispensed with. The 
original copy of the invoice duly checked and completed by the Customs will be handed over to the owner or his agent. Al the same time the duplicate and triplicate copies of the invoice will be despatched by the Custom Ilouse to the Afghan Customs at Spin Baldak.

4. On receipt of the invoice from the Pakistin Customs, the Alghan Customs at Spin Baldak will retain the duplicale and return the tripticalc copy to the Custom House of despatch in Pakistan wilh approprialc endorsement certifying the arrival of the goods.

5. The procedure in respect of goods despatched by the PeshawarTorkham route from Karachi will be the same as detailed up to and including paragraph 3 above in respect of Spin Baldak. The procedure therealter will be that the Custom House will despalch the duplicate and triplicate copies of the invoices to the Customs officer at Peshawar. On receipt of the invoice from the Karachi Customs, the Customs Olfieer at Peshawar shall retain the duplicate and forward the triplicate copy to the Customs (officer at 'Torkham. On arrival at Peshawar such goods will be carried to a transil shed or area under Customs control or transferred direclly 10 a road-Iransport under Customs supervision. Road transports in which the goods are carried forward to Alghanistan will, where possible, be sealed with Customs Seal.

6. Goods which require re-packing after arrival at Peshawar will be allowed re-packing facilities at the Transit shed or area under Customs control. The Custonis Officer at Peshawar will check the goods with the original copy of the invoice and compare the latter with the duplicate cony received from the port of entry. If the seals are intact and the goods correspond with the description in the invoice, the customs Ollicer shall allow the goods to be re-packed and rescaled under his supervision, shall endorse on each copy of the invorice details of any change in the number or description of the packages involved by such re-packing, shall where possible seal the road transport in which the goods are loaded for final transporl to Alghanistan return the original copy of the invoice so endorsed to the owner or his agent and forward the duplicate copy to Customs oflicer at Torkham. On arrivat at Torkham, the goods must be presented to the Customs Officer along with the duplicate copy of the invoice for inspection and final clearance. The Customs Officer shall note the re-packing particulars, if any, on the reverse of the triplicale copy and return the duplicate to the Customs Officer al Peshawar.

7. In the case of goods entering Pakistan at Lahore the procedure will be the same as detailed above in respect of Katrachi exeepe the provisions of paragraph 2 above.

8. The procedure in respect of goods moving into Spin Baldak will be enfored only when the railway line has been extended up to that point. 
Ualil then the formalities provided for in respect of P'eshawat Torhham route will apply mutatis mutandis to Chaman and to the Customs Post opposite Vesh.

9. Afghan goods or passengers' unaccompanied haggage arriving in Iransit by sca at Karachi if moving by air to Afghanistan from Karachi airport, will be transported under Customs seal to Karachi Airport and placed on board the on-carrying aircraft under Customs supervision. The documentation in respect of such goods will be similar to that for goods despatched by rail with approprialc modilications.

II. PROCEDURE IN RESPECT OF GOODS AND PASSENGERS, UNACCOMPANIED BAG(;AGE MOVING; IN TRANSIT FROM AFGHANISTAN TO FOREIGN COUNTRIES THROUGII PAKISTAN.

1. On entry of the goods at the land Customs stations al Torkham/ P'eshawar or at Chaman untit such time as the railway line is extended upto Spin Baldak and Torkham, the Afghan exporter or his agent shall declare that the goods are in transit 10 a third country or overseas and furnish in quadruplicate an invoice in the prescribed form.

2. The Government of Pakistan may require certain specitied gonds despatched in transit from Afghanistan to forcign countries to be sealed by the Afghan Customs before their despatch out of Alghanistan. A list of such goods will be furnished to the Government of Afghanistan from time to time.

3. On compliance with the above provisions the seals on the goods will be checked and the goods removed under Customs Supervision to the Iransit shed or area at the Pakistan railhead at Peshawar or Chaman under Customs control. Re-packing facilitics will be allowed at these transit sheds or areas as well as at the transit shed in the Karachi Port area.

4. The goods will be loaded under Customs supervision into railway wagons exclusively provided for in transit goods which will be sealed by the Railway. The original copy of the invoice duly checked and completed by the Customs will be handed over to the owner or his agent. At the same time, the duplicate and triplicate copies of the invoice will be forwarded by the Frontier Customs officer at the Pakistan railhead to the Collector of Customs, Karachi if the goods are to be exported by sea or to the Land Customs Officer at the Land Customs Station through which the goods are 10 be exported by land to India. The quadruplicate copy will be relained by the fiontier Land Customs Oflicer for his record. The Customs Officer, who supervises the loading of goods into the railway wagens, will record on all copies of the invoiec the numbers of the wagons in which the goods have kecn despatched. 
5. (a) In the case of goods to he exported by sea from the Port of Karachi, the goods will, on arrival at Karachi railway station be unloaded from the wagons under Customs supervision alter verifying that the seals are intact. They will then be carried under Customs supervision to the Afyhat transit shed specially set opart for the purpose in the port areia, under Customs control. The goods will remain in Customs control until they are duly exported on filing of an export shipping bill. The goods will be inspected, and examined if necessary, before shipment is allowed under Customs supervision.

NOTE: Goods of hayardous nature such as colton which are in transit from Afghanistan to foreign countries cannot be stored in the transit shed along with other goods and the present arrangements of storing such goods will continuc.

(b) In the case of goods to be exported by Land to India, the wagons will, on arrival at the Land Customs Station, be inspected by the Customs: Detailed examination of the goods will be dispensed with if the seals on the wagons are intact. The Customs Oflicer will satisfy himself that the seals are intact and that the numbers of the wagons correspond with those entered in the invoice. If the duplicate and triplicate copies of the invoice have not been received from the Frontier Customs. Officer he will not detain the goods but will pass them after entering the verificd particulars of the wagons and if necessary of the goods owner or his agent. On receipt of the duplicale and triplicate copies of the invoice, he will make the necessary endorsement on the basis of the particulars recorded in his register.

6. After the goods have been duly shipped for export by sea or handed over to the railway authoritics for onward transmission by land, the Customs Officer will certify on each copy of the invoice that the goods have been duly shipped or exported. The original copy of the invoice will be returned to the owner or his agent, the duplicate copy will be sent to the Froncier Customs Officer at Peshawar or Chaman, as the case may be, and the triplicate copy will be relained for record by the Custom House, Karachi, or the Land Customs Station of export, as the case may be.

7. As soon as the Railway line is extended to Spin Baldak and Torkham the documentation and sealing of packages in respect of such goords will be the responsibility of the Afghan Custons, the scaling of wagons being done by the Railway, the detailed procedures respecting which will be drawn up by mutual consultation by representatives of the two Governments.

Orfences and penalties.--See clause (64) of section 156(1) of the Ad. 
88

RELEVANT EXTRACTS

from
THE EXPORT POLICY ORDER, 1990

GOVERNMENT OF PAKISTAN 


\section{9 \\ The \\ EXPORT POLICY ORDER. \\ 1990}

Notincation No. S.R.O. 697(1)/90, dated 1st July, 1990.-in exercise of the powers conferred by sub-section (1) of section 3 of the Imports and Exports (Control) Act, 1950 (XXXIX of 1950), and in supersession of the Ministry of Commctce Notification No. S.R.O. 550(1)/8j, dated the 29th June, 1987 and all subsequent amendments made thereunder, the Federal

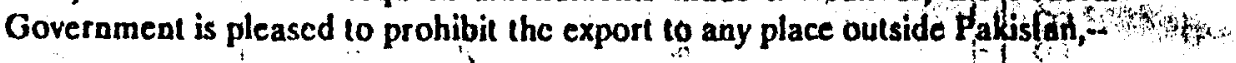

(A) of any goods of the description specified in Schedule 1 ; and

(B) of any goods of the description specified in Schedules II to [ $[V 1$,$] otherwise than in accordance with the conditions and$ restrictions specified in those Schedules, except-- |

(a) any goods cove: $: \mathrm{C}$ by an export licence issued by or under the orders of the Ministry of Commerce,

Chief Controller, Controller; Deputy Conitoller or Assistant Contruller of Imports and Exports: Provided that in the case of goods falling urider entry No. 1 in Schedule I such expori licençe shall be accompanied by health certificate issued by a vetcrinary officer authorised by the fFederal

Government in this behalf; $8,1,+1$

(b) any goods constituting the stọres or equipment of any outgoing vessel or conveyance or the boid fide baggage of the crew or of the passengers in such vessel or conveyance;

(c) any goods transhipped at a port in Pakstan after having been manifested for such transhipment at the time of despatch from a port outside Pakistin;

(d) any goods consigned under a procedure prescribed for regulating transit traffic; ?

(c) ... any goods except jute seed, artemisia seeds and fissionable malerials forming contents of a bona fide sample: Provided that when such peteds and materials are sent by post those shall be subject to

\section{i.} It should be $V$ as the policy contains only Five Schedules anmely Schedples I, II, III, IV and $V$. 
ti

- If:

(I)

1..1, $1:$

i....

$! i, \quad$ (g)

(b)

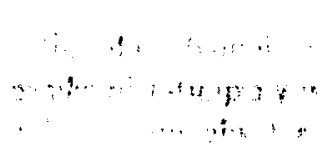

..:

(i)

5etiol.

+. . . . . . .

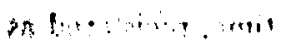

$\therefore ? \quad 1=\because 2 \pi$

$\therefore \quad 1$

;i the postal rigulations regarding limits of maximum weight for different countries for the time being in force;

any goods exported under a procedure prescribed for regulating trade between border areas of Pakistan and those of the adjacent territories;

wheat and wheat products from Pakistan to Azad Kashmir territory;

any stores or equipment when sold abroad on Government to Government basis and exported under an export licence issued by the Director of Pakistan (Army) or by any other officer authorised by the Ministry of Defence; $\therefore \quad, \quad, \quad \therefore$ a

bona fide samples or articles exported bs stich by an exporter in Pakistan provided that -. 1 noilksilinis?

(a) the f.o.b. value of each consignment of sample does nol exceed US 1000 : Provided that leather" garment manufacturers are entitled to export fifty samples in a calendar year, irrespective of monctary ceiling;

(b) the samples are supplied free of charge;

(c) the consigner is registered exporter under the Registration (Importers and

. Exporters) Order, 1952, or has been exempled from registration thereunder; and

(d) all gift parcels of the value not exceeding Rs. $\mathbf{5 0 0}$ each.

2. All exporters, other than organizations in public sector, when applying for export registration or renewal of existing export registration shall, among othet things, produce a certificate of membership of any of the trade organizations licensed or recognised by the Federal Government under the Trade Ordinance, 1961 (X'LV of 1961), to be--

(i) on All-Pakistan Association of Trade or Industry or both, representing the specific trade or industry of the exporters: Provided that if the exporte: is engaged in more than one - trade or industry and becomes a member of an All-Pakistan 
: . . Association representing any such trade or industry it shall . ..... ....it . not be compulsory for such exporter to become a member of any other such Association representing other trade or industry; or

r. (ii) a Chamber of Commerce and Industry of the area in which head office of the exporter is located and whicb is affiliated to the Federation of Pakistan, Chambers of Commerce and Industry: Provided that in case the exporter is removed by such Chamber from its meiribership, such exporter may become a member of any other Chamber so affiliated and produce a membership certificate from the latter Chamber:

Provided further that the certificate shall be issued only after verification of the bona fide of the exporter, and that if any exporter in whose favour a membership certificate has been issued by a trade organization ,found by the licensing authority to be not genuine or non-existent, the certification by such trade organization shall noi be acted upon:

Provided further that in case an existing exporter fails to register himself with a tradeg organization licensed or recognised by the Federal Government, his export registration shall be cancelled:

'Próvided also that an exporter, who is, at the same time, registered as an importer shall be exempt from the above condition.

3. Provisions of this Order shall come into force on the first day of July, 1990 , and shall remain in force until the 30th day of the June, 1991, without prejudice to the powers of the Federal Government to amend this order in the larger economic and national interest.

\section{SCIIEDULE 1}

\section{ESSENTIAL COMMODITIES}

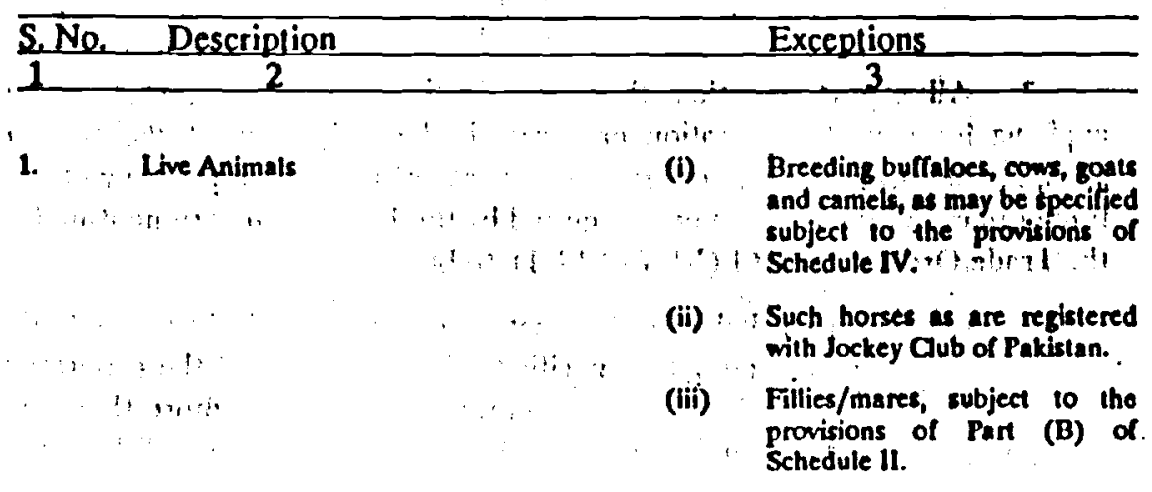


2 Beef and mutton.

3. Animal fal.

4. Milk and milk products.

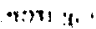

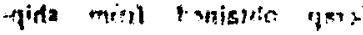
n...:

bis: and fotbiallu soits. noitinumrat lne asionsto
6.
Peppet. : :

7. Pulses and beans, all sorts.

4. 8. Bloodrmeals, tmeat meals, com

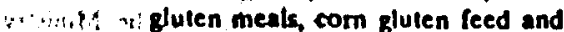
$3 y+3$ if l herrestante oil cakes, ,

\$. $\quad$ Bran and todder, all sorts.

10.,... Sann hemp and artemisia seeds.

11. Edible "oils, "all 'sorts, including rilinm:? bulter oil and regetable ghee and oil-seeds.

-1! ?., th

12, , pounder.

13. Intoxicants and intoxicating liquors as defined in the Prohibition (Enlorcement of Iladd) Order, 1979. (iv) . Poultry, . live or dreseed including day old chicks.

(v) Fush, shrimps, lobsters, crabs and frook.

(vi) Wild boar.

(i) Cooked and canned beef and mutton.

(ii) $50 \%$ of the total ptoduction of cöminercial leed bl units, livestock farms and bilateral - joint ventures.

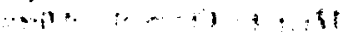

(i) Infant tormula lood, infant weaning foods and foods for imvalids.

(ii) ., Cheeses:

(iii) UITT milk (upto so\% of production of eech wait).

(iv) $:$, . lee Cream

(v) Yoghurt.

Maize and bartey (subject to quota).

Crushed/poudered black pepper in packets.

Oil cakes, rice bran, wheat bran (subject to quota and special procedure). . . ss

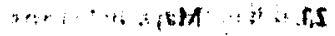

Castor seeds, poppy seeds, tupok seeds and sesame seeds.

$$
\therefore \text { sind }
$$




123

'14." Hides the skins, will sorts."

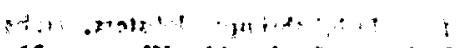

15. Wet blue teather made from cow hides and cow ealf-hides.

16. Wild animal skins and garmenis made of tuch stins; products or derivatives of such stins; finished or

in ins: : -fanned leather made of wild animal

1.... i skinsy and stuffed mounted or

aiv ing i presenved specimens of wild animals, ...

17. Charcosl and firewood.

1.18. is . Timber, $+\infty$ ! , '

"19. Ethply odth crales, assembled or unasiembled.

20. Terrous and hion-ferrous metals.

ir* ro nis $n$

21. Ams $1 \mathrm{Ag}$ ammunitions and explosives and ingredicnts thercol.

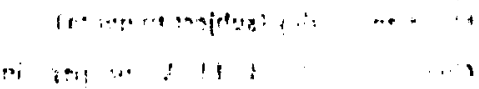

22. in Fissionable malefial.

23. Mape and charts.

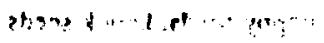

$3^{\prime}$

24. Unfinished and semi-finished hockey sticks and blades.

25. Paperwaste.

26. Iluman skeleions. (i) Lamb skins (gradek i to V).

(ii) Wild boar stins. (i) Pigiron.

(ii) Scrap oblained Irom shipbrealing.

(i) Knives.

(ii) Sporting, rifles, hand guns and acressories and ammunition thereol. $1 \times 1+1$ ?

(iii) Saltpetre:

(iv) Arms. ammunilions, explosives and ingrebients thereof recommended by' the Ministry of Foteign Affairs and Defence Production Division.

(i) Maps of ccalé straller than 1/4* , or, $1 / 250,000,4, ;$

(ii) 'de: Educational wind scientific chants. $"$, ti.

(iii) Guide maps and Rliel mapd! of min?

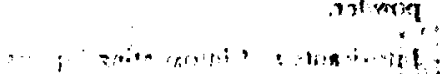


1 2

27. Ali imported goods in their original or un-processed form.

(i) Parts obiained "Irom shipbreaking.

(ii) Scrapped battery cells.

(iii) Waste dental amalgam.

(iv) Waste exposed $X$-ray films.

(v) Over 20 years old automolive vehicles and aircrafts, provided export earnings are received in foreign exchange.

(vi) Imported goods in their original or unprocessed form provided their re-export f.o.b. price is higher by at least $10 \%$ than their C\&E prices. 'The goods would be tre-exporied against licence and re-exports would be alfecied either tapainsi udvarice payment ór' agatinst sight kller of eredit:- in : islt

28,... Antiquities.

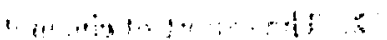

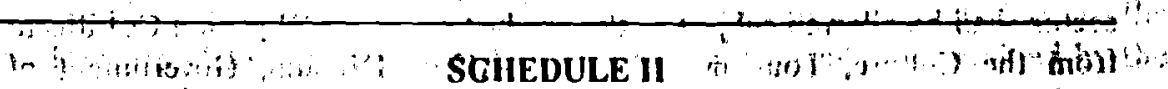

\section{(A) COMMODITIES EXPORTABLE THROUGH PUBLIC SECTOR}

1. :

The lollowing items will be exported only through public sector

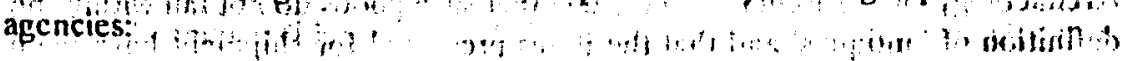

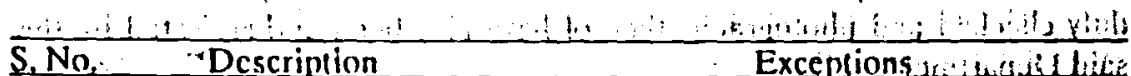
1 Excen

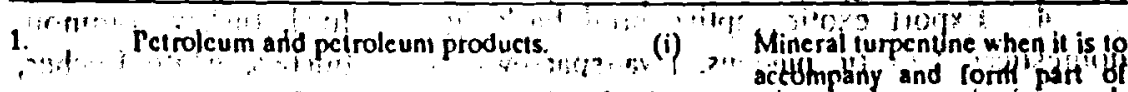
3

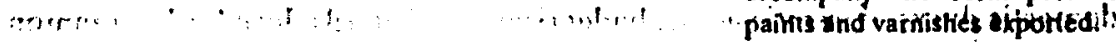

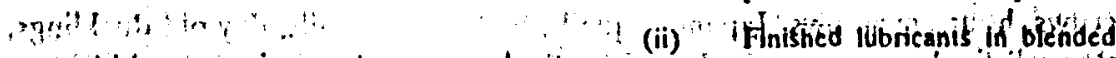

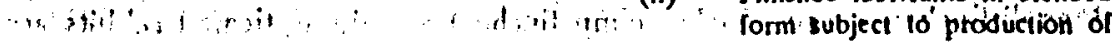

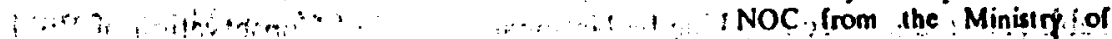

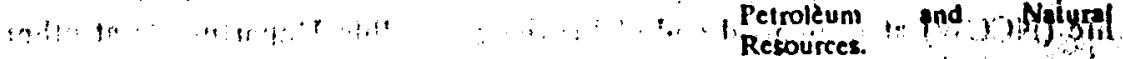

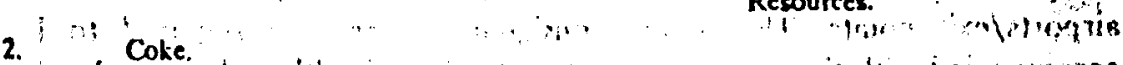

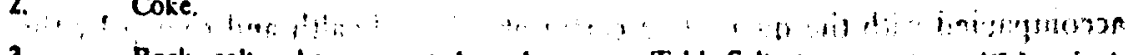

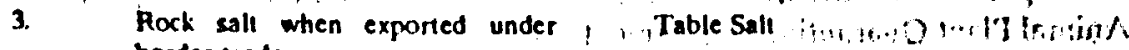
border trade.

4.: "Sodiun hydróxide (Caustic Soda). 


\begin{tabular}{lll}
\hline $1 \cdot 2$ & 3 & \\
\hline
\end{tabular}

S. Raw cotton, Including desi colton.

6. Rice.

7. Cement.

,
As per CEC/RECP Policy of private. Leclor participation and Government policy of linduction of privite sector in collon and rice trade.

As per CEC/RECP Policy of private sector participation and Government policy of induction of private sector in colton and rice trade.

As per CEC/RECP Policy of privale sector participation and Government policy of induction of privale sector in colton and rice trade.

(B) COMMODITIES EXPORT OF WHICH IS SUBJECT TO SPECIAL un: $\cdot 1$ PROCEDURES

.11

1. The export of precious and semi-precious stones and gold jewellery (itcluding gold jewellery cmbcdded with indigenous or imported precious or semi-precious stones) shall be governed by the special procedure notified by the Export Promotion Bureau.

2. The export of cinematographic films produced in Pakistan by private sector shall be allowed subject to the production of No Objection Certificate from the Culture, Tourism and Youth Affairs Division, Government of Pakistan.

3. The export of used copper and brass utensils shall be allowed subject to the production of No Objection Certificate from the Department of Archacologi and Muscums to the effect that such goods do not fall within the definition of 'antiques' and that the items presented for shipment have been duly checked and photographs thereof have also been authenticated by the said Department:"

4. Export exotic captive bred birds (guinea fowl, turkey, common, domesticated/cxotic pigeons, java sparrows, zebra finches, white finches, domestic ducks; domestic geesc, budgerigars, cockaterils, love birds, common crows, house sparrows, Japanese quails, bod white, quails, day old ducklings, Bengali finches, serene finches gimp finches) and domesticated rabbits are subject tó mandatory checking by National Council of Conservation of Wildlifé (NCCW) at Islanabad and of Provincial Wildlife Departments at other airports/exit points. The export consignments are also required to be accompanied with the quarantine certificate about health and caging by the Animal Plant Quarantine Department.

5. Export of Endemic birds will be subject to mandatory checking by 
the NCCW at Islamabad and of Provincial Wildife Department at other airports/exit points. Export consignments of rose ringed parakeet (psittacula krameri) will be accompanied by the Convention on International Trade in Endangered Species of Wild Fauna and Flora (CrTES), export certificate issued by the National Council of Conservation of Wildlife (NCCW). The following 'two ' scientific institutions will, however, be exempt from the requirements of plants and animals, including insects, for scientific purpose, namely:--

(i) Pakistan Agricultural Research Council, Islamabad, and

(ii) Commonwealth Institute of Biological Control, Rawalpindi.

6. Export of atta, suji, maida and wheat bran will be subject to distribution of quota by the Pakistan Flour Mills Association.

7. Export of fillics and mares will be subject to clearance by a Comimittee comprising representatives of the Remount, Veterinary and Farms under GHQ, Livestock Division, Jockey. Club of Pakistan and Horse Breeders' Association. Horses other than fillies and mares registeted with Jockey. Club of Pakistan can be exported after obtaining an identification certificate from Jockey Club of Pakistan and export permit from-the. Chief Controller of Imports and Exports.

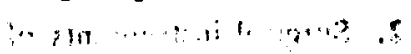

8. Export of fertilizers is authotised by a Standing Committee in the Ministry of Industries on the basis of exportable surplus determitied by the Government.

9. Export of Basmati rice by private sector is allowed in packets with. brand names or in bulk subject to the conditions that (i) the exporters ate registered with the respective Chambers of Commerce and Industry (ii) the brand names will be registered with the Registrar Trade Marks, Government of Pakistan (iii) the exportters may obtain rice either from Rice Export

5. Corporation of Pakistan Ltd. (RECP) or may use their own;stocks (iv) the buyer shall àpooint internationally repuled inspectors or RECP for inspestion and (v) the contracts shall be subject to approval and registration by the Export Promotion Bureau (EPB).

10. Export of colton by the private sector shall be subject to such procedure as may be specified by the Federal Government by Notification in the official Gazette.

11. Export of wild boar, its meat and skin shall be permissible ionly by. the non-muslim registered exporters.

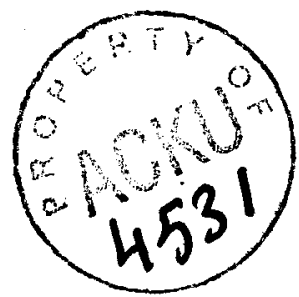

